\author{
Mariusz Barańskia ${ }^{a}$, Agnieszka Haznar-Barańska ${ }^{\text {b) }}$ \\ a) Lodz University of Technology, Faculty of Process Engineering and Environmental Protection / Politechnika Łódzka, Wydział \\ Inżynierii Procesowej i Ochrony Środowiska \\ b) Municipal Roads and Greenery Authority in Oława / Zarząd Dróg Miejskich i Zieleni w Oławie \\ *Corresponding author / Autor korespondencyjny: mariusz.baranski@o2.pl
}

\title{
Evacuation and its Types - Revision of the Definition and Classification
}

\section{Ewakuacja i jej rodzaje - rewizja definicji oraz klasyfikacja}

\begin{abstract}
Objective: Evacuation is a broad concept encompassing many forms of movement in the event of an emergency. Definitions of evacuation are different in many standards and publications in the field of fire safety engineering. The introduction of a unified version of the definition will allow for a precise description of this process. The diversity of its forms and types in the literature on the subject requires the introduction of an appropriate classification. This will allow for systematization of various forms of evacuation and conducting more precise research on individual types of the evacuation process. Introduction: The evacuation process takes into account the possibility of moving not only people, but also animals and property from a place of danger to a currently safe place. It is a process that does not always take place in an organized or orderly way, and its effect is to leave the place of danger by all people. The complexity of the evacuation process allows it to be divided due to various forms, ways of conducting it, or objects subject to evacuation. In the literature on the subject, many definitions of various forms of evacuation have been formed, i.e. general, phase, organized, self-evacuation, independent, rescue, primary, gradual, selective, sequential, full, preventive, partial, successful, total, successful, successful, secondary, primary, intervention, managed, directed, unmanaged, I degree, II degree, III degree, etc.

Methodology: The authors reviewed the available definitions of the concept of evacuation and proposed a new definition to describe the process in more general terms. In addition, the authors conducted a review of the forms of evacuation and its classification occurring in scientific publications within the national scope. As a result of the detailed analysis, a preliminary classification of individual determinations of the evacuation process was made. Conclusions: The concept of evacuation has a much broader meaning than the current definitions of this process. The analysis shows that evacuation should be defined as a process of moving people, animals or property from a place of danger to a place currently safe. For the purposes of this article, a total of more than 25 evacuation process determinations have been identified, which have been classified into 12 categories. Progress in many areas, i.e. construction, development of transport and urban infrastructure and the occurrence of public demonstrations/events, affects the need to verify existing definitions for the needs of new conditions. The publication aims to draw attention to the need to introduce a systematic analysis of the classification of the evacuation process. Such classification will allow for the proper identification of all kinds of variables that have different effects on different forms of this process. The introduction of such a division will allow the use of appropriate measures, tools and procedures to ensure an adequate level of human safety. The carried out categorization may be the basis for identifying the risks that may occur during individual forms of evacuation. Keywords: evacuation, evacuation definition, types of evacuation, fire safety
\end{abstract}

Type of article: review article

Received: 19.10.2021; Reviewed: 08.11.2021; Accepted: 15.11.2021;

Author`s ORCID IDs: M. Barański - 0000-0002-2217-6539; A. Haznar-Barańska - 0000-0001-7648-509X;

Percentage contributon: M. Barański - 70\%; A. Haznar-Barańska - 30\%;

Please cite as: SFT Vol. 58 Issue 2, 2021, pp. 204-222, https://doi.org/10.12845/sft.58.2.2021.12;

This is an open access article under the CC BY-SA 4.0 license (https://creativecommons.org/licenses/by-sa/4.0/).

\section{ABSTRAKT}

Cel: Ewakuacja jest szerokim pojęciem obejmującym wiele form przemieszczania w przypadku zagrożenia. Definicje ewakuacji są odmienne w wielu normach oraz publikacjach z zakresu inżynierii bezpieczeństwa pożarowego. Wprowadzenie ujednoliconej wersji defınicji umożliwi precyzyjne opisanie tego procesu. Występująca w literaturze przedmiotu różnorodność jej form i rodzajów wymaga wprowadzenia odpowiedniej klasyfikacji. Pozwoli to na systematyzowanie różnorodnych form ewakuacji oraz prowadzenie bardziej precyzyjnych badań poszczególnych rodzajów procesu ewakuacji.

Wprowadzenie: Proces ewakuacji uwzględnia możliwość przemieszczania nie tylko ludzi, ale także zwierząt i mienia z miejsca zagrożenia do miejsca aktualnie bezpiecznego. Jest to proces, który nie zawsze przebiega w sposób zorganizowany czy uporządkowany, a jego efektem jest opuszczenie miejsca zagrożenia przez wszystkie osoby. Złożoność procesu ewakuacji pozwala na dokonanie jej podziału ze względu na różnorodne formy, sposoby jej prowadzenia, czy obiekty podlegające ewakuacji. W literaturze przedmiotu ukształtowało się wiele określeń różnych form prowadzenia ewakuacji, tj. ewakuacja 
powszechna, fazowa, zorganizowana, samoewakuacja, samodzielna, ratownicza, pierwotna, stopniowa, selektywna, sekwencyjna, pełna, prewencyjna, częściowa, udana, całkowita, pomyślna, wtórna, pierwotna, interwencyjna, zarządzana, kierowana, niezarządzana, I stopnia, II stopnia, III stopnia, itp. Metodologia: Autorzy dokonali przeglądu dostępnych definicji pojęcia ewakuacji oraz zaproponowali nową definicję pozwalającą na opisanie procesu w sposób bardziej ogólny. Ponadto autorzy przeprowadzili przegląd form ewakuacji oraz jej klasyfikacji występujących w publikacjach naukowych o zasięgu krajowym. W wyniku szczegółowej analizy dokonano wstępnej klasyfikacji poszczególnych określeń procesu ewakuacji.

Wnioski: Pojęcie ewakuacji ma znacznie szersze znaczenie niż określają to obecnie obowiązujące definicje tego procesu. Z dokonanej analizy wynika, że ewakuację należy definiować jako proces przemieszczania ludzi, zwierząt lub mienia z miejsca zagrożenia do miejsca aktualnie bezpiecznego. Na potrzeby niniejszego artykułu zidentyfikowano łącznie ponad 25 określeń procesu ewakuacji, które zostały sklasyfikowane według 12 kategorii. Postęp w wielu dziedzinach, tj. budownictwo, rozwój transportu i infrastruktury miast oraz występowanie publicznych manifestacji/imprez wpływa na potrzebę zweryfikowania istniejących definicji na potrzeby nowych uwarunkowań. Publikacja ma na celu zwrócenie uwagi na konieczność wprowadzenia usystematyzowanej analizy klasyfikacji procesu ewakuacji, która pozwoli na właściwą identyfikację wszelkiego rodzaju zmiennych mających odmienny wpływ na różne formy tego procesu. Wprowadzenie takiego podziału umożliwi zastosowanie odpowiednich środków, narzędzi oraz procedur do zapewnienia odpowiedniego poziomu bezpieczeństwa ludzi. Przeprowadzona kategoryzacja może być podstawą do zidentyfikowania zagrożeń mogących występować podczas prowadzenia poszczególnych form ewakuacji.

Słowa kluczowe: ewakuacja, definicja ewakuacji, rodzaje ewakuacji, bezpieczeństwo pożarowe

Typ artykułu: artykuł przeglądowy

Przyjęty: 19.10.2021; Zrecenzowany: 08.10.2021; Zaakceptowany: 15.11.2021;

Identyfikatory ORCID autorów: M. Barański - 0000-0002-2217-6539; A. Haznar-Barańska - 0000-0001-7648-509X

Procentowy wkład merytoryczny: M. Barański - 70\%; A. Haznar-Barańska - 30\%;

Proszę cytować: SFT Vol. 58 Issue 2, 2021, pp. 204-222, https://doi.org/10.12845/sft.58.2.2021.12;

Artykuł udostępniany na licencji CC BY-SA 4.0 (https://creativecommons.org/licenses/by-sa/4.0/)

\section{Introduction}

The concept of evacuation, as well as its variants, over the years have been given many terms. On the basis of reading articles in scientific journals, several terms regarding the evacuation process can be specified. This causes chaos in terms of its definition and classification. Adjectives specifying the evacuation process are diverse and depend on its specificity, which is fully justified. It can be stated with all firmness that the classification of evacuation requires systematization. Taxonomy makes it possible to organize various forms of the evacuation process.

The authors of the article attempt to unify the definition of the concept of evacuation and its classification. It will facilitate research on issues related to evacuation. Appropriate assignment of individual types of evacuation and their groups will allow to develop the best methods of ensuring safety, also during evacuation. Proper classification will in turn ensure that the risks associated with various forms of evacuation can be carried out. This will allow to design an evacuation process, as well as direct this process in a way that ensures the highest level of safety.

\section{Ensuring safety of people in facilities}

Safety of people is paramount. Guarantees of its provision have already been included in the Constitution of the Republic of Poland (among others articles 5 and 66) [1]. Based on this, human safety conditions which are to be ensured in construction works have been defined in detail [2]. Buildings should be designed and constructed in such a way as to ensure that people can be

\section{Wprowadzenie}

Pojęcie ewakuacji jak również jej warianty na przestrzeni lat doczekały się wielu określeń. Na podstawie lektury artykułów w czasopismach naukowych można wyszczególnić kilkanaście określeń dotyczących procesu ewakuacji. Powoduje to chaos w zakresie jego definiowania oraz klasyfikacji. Przymiotniki precyzujące proces ewakuacji są zróżnicowane i uzależnione od jej specyfiki, co jest w pełni uzasadnione. Z całą stanowczością można stwierdzić, że klasyfikacja ewakuacji wymaga usystematyzowania. Taksonomia umożliwia organizację różnorodnych form procesu ewakuacji.

Autorzy artykułu podejmują próbę ujednolicenia definicji pojęcia ewakuacji oraz jej klasyfikacji. Ułatwi to prowadzenie badań nad zagadnieniami związanymi z ewakuacją. Odpowiednie przyporządkowanie poszczególnych rodzajów ewakuacji oraz ich grup pozwoli wypracować jak najlepsze metody zapewnienia bezpieczeństwa, także $w$ trakcie prowadzenia ewakuacji. Właściwa klasyfikacja zapewni z kolei możliwość prowadzenia analizy ryzyka związanego z różnymi formami ewakuacji. Pozwoli to na projektowanie procesu ewakuacji, a także kierowanie tym procesem w sposób zapewniający największy poziom bezpieczeństwa.

\section{Zapewnienie bezpieczeństwa ludzi w obiektach}

Bezpieczeństwo ludzi jest wartością nadrzędną. Gwarancje jego zapewnienia znalazły się już w Konstytucji RP (m.in. art. 5 i 66) [1]. $\mathrm{Na}$ tej podstawie szczegółowo zostały określone warunki bezpieczeństwa ludzi, które należy zapewnić w obiektach budowlanych [2]. Budynki powinny być projektowane i wykonane w sposób zapewniający możliwość ewakuacji ludzi lub ich uratowania w inny sposób 
evacuated or otherwise rescued in the event of a fire (3). This postulate is currently indisputable and must be met for every building used. In Europe [4] and in Poland, a broad legal and standardization apparatus is being introduced to meet the above postulate [2-3].

Persons responsible for safety in buildings, in addition to legal regulations, have at their disposal a number of national and foreign norms and standards [5-7], as well as technical knowledge [8] collected in scientific publications.

\section{The concept of evacuation}

The origin of the concept of evacuation should be sought in Latin. Initially, the meaning was sought in the word văcuŏ meaning to make something empty or invalid, or ê-văcuŏ meaning to empty, evacuate [9]. Some authors point to another concept derived from another Latin word evacuatio meaning emptying, disappearing or evacuare meaning emptying, disappearing [10]. A later form is the French word évacuation. In many languages, this term functions in a similar form - evacuation, ger. Evakuierung, rus. Эвакуация (évakuaciâ), sp. evacuación, cz. evakuace, sl. evakuácia, esper. evakuado and many others.

Over the years, the concept of evacuation has evolved. The dictionary of foreign words defines them as the export of people or property from areas threatened by a cataclysm or war. Another definition is found in the Dictionary of the Polish Language and states that it is the transport of people, animals and belongings from areas threatened by war or haunted by a natural disaster. In turn, the Dictionary of the Modern Polish Language indicates that evacuation is the removal, removal of civilians or the army, movable property, equipment, etc. from the area of danger (e.g. in time of war or natural disaster, major accident, etc.). The Great Dictionary of Foreign Words shows that evacuation is the taking away of people, belongings, etc. from areas threatened by the enemy or an element (e.g. flood). A more extensive definition can be found in the instruction of the Head of Civil Defence of the Country on the principles of evacuation of people, animals and property in the event of a mass threat [11], according to which evacuation is the movement of people and animals, as well as the transport of property to safe places from areas where there are threats (areas where there are no threats to human and animal life or health, as well as the environment and property at a given time).

This concept is defined differently in the Polish Standard, in which evacuation is an orderly movement of people to a safe place [12]. In turn, the American standard NFPA 1616 [13] gives four terms for the concept of evacuation, as:

- evacuation activity or process,

- leaving or removing someone from a dangerous place,

- withdrawing from a potential area of impact in an organised manner, in particular for conservation,

- organised, phased and supervised withdrawal, dispersal or removal of civilians from hazardous or potentially dangerous areas and their reception and care in safe areas.

However, the presented definitions do not fully refer to the current threats. The intensively developing space around us w przypadku powstania pożaru [3]. Ten postulat jest obecnie niepodważalny i musi być spełniony dla każdego użytkowanego budynku. W Europie [4] oraz w Polsce wprowadza się szeroki aparat prawny oraz normalizacyjny, aby spełnić powyższy postulat [2-3].

Osoby odpowiedzialne za bezpieczeństwo w budynkach oprócz uregulowań prawnych mają do dyspozycji szereg norm i standardów krajowych oraz zagranicznych [5-7] oraz wiedzę techniczną [8] zebraną w publikacjach naukowych.

\section{Pojęcie ewakuacji}

Pochodzenia pojęcia ewakuacji należy poszukiwać w języku łacińskim. Początkowo znaczenia doszukiwano się w słowie văcuŏ oznaczającym uczynienie czegoś pustym lub nieważnym, lub ē-văcuŏ oznaczającym opróżnić, ewakuować [9]. Niektórzy autorzy wskazują na inne pojęcie pochodzące od innego łacińskiego słowa evacuatio oznaczającego opróżnienie, znikanie lub evacuare oznaczającego opróżnianie, znikanie [10]. Późniejszą formą jest francuskie słowo évacuation. W wielu językach termin ten funkcjonuje w zbliżonej formie - ang. evacuation, niem. Evakuierung, ros. Эвакуация (évakuaciâ), hiszp. evacuación, czes. evakuace, słow. evakuácia, esper. evakuado i wiele innych.

Na przestrzeni lat pojęcie ewakuacji ewaluowało. Słownik wyrazów obcych definiuje je jako wywożenie ludności lub majątku z terenów zagrożonych kataklizmem, wojną. Inna definicja znajduje się w Słowniku języka polskiego i podaje, że jest to wywożenie ludzi, zwierząt i dobytku z terenów zagrożonych wojną lub nawiedzonych klęską żywiołową. Z kolei Słownik współczesnego języka polskiego wskazuje, że ewakuacja jest to usuwanie, wywożenie ludności cywilnej lub wojska, majątku ruchomego, sprzętu itp. $z$ terenu zagrożenia (np. w czasie wojny lub klęski żywiołowej, poważnej awarii itp.). Z lektury Wielkiego słownika wyrazów obcych wynika, że ewakuacja jest to wywożenie ludzi, dobytku itp. z terenów zagrożonych przez nieprzyjaciela lub żywioł (np. powódź). Bardziej rozbudowana definicja znajduje się w instrukcji Szefa Obrony Cywilnej Kraju w sprawie zasad ewakuacji ludności, zwierząt i mienia na wypadek masowego zagrożenia [1 1], zgodnie z którą ewakuacja to przemieszczenie się ludności i zwierząt, a także transport mienia z rejonów, w których występują zagrożenia, do miejsc bezpiecznych (obszarów, na których $w$ danym czasie nie występują zagrożenia dla życia lub zdrowia ludzi i zwierząt oraz środowiska i mienia).

Inaczej definiowane jest to pojęcie w Polskiej Normie, w której ewakuacja jest to uporządkowany ruch ludzi do miejsca bezpiecznego [12]. Z kolei norma amerykańska NFPA 1616 [13] określa pojęcie ewakuacji jako:

- czynność lub proces ewakuacji,

- opuszczenie lub usunięcie kogoś z niebezpiecznego miejsca,

- wycofanie się z potencjalnego obszaru oddziaływania w sposób zorganizowany, zwłaszcza w celu ochrony,

- zorganizowane, etapowe i nadzorowane wycofywanie, rozpraszanie lub usuwanie ludności cywilnej z obszarów niebezpiecznych lub potencjalnie niebezpiecznych oraz ich przyjmowanie i opieka w obszarach bezpiecznych.

Prezentowane definicje nie odnoszą się jednak w pełni do występujących obecnie zagrożeń. Intensywnie rozwijająca się 
requires a revising of the concept of evacuation and taking into account new threats and trends in ensuring the safety of people. Currently, the concept of evacuation refers to a wide range of activities. The authors propose a unified definition taking into account a number of different forms of the process of moving both people, animals and property in the event of an emergency. The definition should be legible, not too long or detailed, written in accessible language, allowing the reader to quickly get acquainted with it.

\section{Evacuation is the process of moving people, animals or property from a place of danger to a currently safe place}

The word movement has a broader meaning than moving, because it can take place without the participation of the moved entity. Bearing in mind movement, we can consider both the movement of people, animals or property using means of transport, as well as independent movement of people after the announcement of an alarm calling for evacuation. People, animals or property in the current form of the evacuation process completely exhaust the list of values subjected to the evacuation process. Determining the place from which the evacuation is carried out also indicates the need for a hazard. It is not only the movement of persons, animals or property from place $A$ to place $B$, but it is movement in a situation where there is a threat to these objects. Therefore, there may be no danger to animals or humans, but only to property. Thus, the evacuation may concern one object or a selected combination of them. Ultimately, it is necessary to define the final location of the evacuation process, as not every place is appropriate. We cannot carry out the evacuation process from one place of danger to another. It is crucial that the destination of the evacuation process is a safer place, providing at least minimal conditions for survival or rescue. In case of humans, they may be better than the critical conditions for the evacuation process [14]. An essential element of the evacuation process is also the need to forecast the development of threats. A situation in which people have to be evacuated again to another potentially safer place in a short time must not be allowed, because the conditions in the previously potentially safe place have deteriorated.

In the space around us, safe places are considered to be spaces in which there is no real threat (objective factor) and a sense of danger (subjective factor) [15-17]. Therefore, safety also depends on a person's individual assessment of its level. In the opinion of a particular user, a safe place must meet his specified minimum expectations.

Security depends on the actual threat. This threat does not have to be directly noticeable by a person, but is the result of a measurement with a specific device or expert assessment of emergency services. In the practice of emergency services, there are cases that people in a situation of real (actual) threat (e.g. carbon monoxide poisoning) do not notice it and are not convinced of the need to evacuate. Only the actions of the services consisting in measuring the concentration of carbon monoxide and przestrzeń wokół nas wymaga zrewidowania pojęcia ewakuacji oraz uwzględnienia nowych zagrożeń oraz trendów zapewniania bezpieczeństwa ludziom. Obecnie pojęcie ewakuacji odnosi się do szerokiego wachlarza działań. Autorzy proponują ujednoliconą definicję uwzględniającą szereg różnorodnych form procesu przemieszczania zarówno ludzi, zwierząt, jak i mienia w sytuacji występowania zagrożenia. Definicja powinna być czytelna, niezbyt długa ani szczegółowa, napisana przystępnym językiem, umożliwiająca czytelnikowi szybkie zapoznanie się z nią.

\section{Ewakuacja jest to proces przemieszczania ludzi, zwierząt lub mienia z miejsca zagrożenia do miejsca aktualnie bezpiecznego}

Słowo przemieszczanie ma znaczenie szersze niż przemieszczanie się, gdyż może odbywać się bez udziału podmiotu przemieszczanego. Mając na uwadze przemieszczanie możemy rozpatrywać zarówno przemieszczanie ludzi, zwierząt czy mienia przy użyciu środków transportu, jak również samodzielne przemieszczanie się ludzi po ogłoszeniu alarmu wzywającego do ewakuacji. Ludzie, zwierzęta lub mienie w obecnym kształcie procesu ewakuacji kompletnie wyczerpują listę wartości poddawanych procesowi ewakuacji. Określenie miejsca, z którego prowadzona jest ewakuacja, wskazuje również na konieczność występowania zagrożenia. Nie jest to wyłącznie przemieszczanie z miejsca A do miejsca B osób, zwierząt lub mienia, ale jest to przemieszczanie w sytuacji, gdy wystąpi zagrożenie dla tych obiektów. Może zatem nie występować zagrożenie dla zwierząt lub ludzi, lecz jedynie dla mienia. Zatem ewakuacja może dotyczyć jednego obiektu lub wybranej ich kombinacji. Ostatecznie wskazanie definicji miejsca końcowego procesu ewakuacji jest niezbędne, gdyż nie każde miejsce jest właściwe. Nie możemy prowadzić procesu ewakuacji z jednego miejsca zagrożenia do drugiego. Kluczowe jest, aby miejsce docelowe procesu ewakuacji było miejscem bardziej bezpiecznym, zapewniającym co najmniej minimalne warunki przetrwania lub uratowania. W przypadku ludzi mogą stanowić one warunki lepsze niż warunki krytyczne prowadzenia procesu ewakuacji [14]. Niezbędnym elementem prowadzenia procesu ewakuacji jest również konieczność prognozowania rozwoju zagrożeń. Nie można dopuścić do sytuacji, w której trzeba będzie w krótkim czasie ponownie ewakuować osoby do innego miejsca potencjalnie bezpieczniejszego, ponieważ warunki w miejscu do tej pory potencjalnie bezpiecznym uległy pogorszeniu.

W otaczającej nas przestrzeni za miejsca bezpieczne uznawane są takie przestrzenie, w których brak jest rzeczywistego zagrożenia (czynnik obiektywny) i poczucia zagrożenia (czynnik subiektywny) [15-17]. Bezpieczeństwo zależy zatem również od indywidualnej oceny jego poziomu przez daną osobę. W odczuciu konkretnego użytkownika miejsce bezpieczne musi spełniać jego określone minimalne oczekiwania.

Bezpieczeństwo uzależnione jest od rzeczywistego zagrożenia, które nie musi być bezpośrednio zauważalne przez człowieka. Stanowi ono efekt dokonania pomiaru określonym urządzeniem lub ekspercką oceną służb ratowniczych. W praktyce służb ratowniczych występują przypadki, że ludzie w sytuacji realnego (rzeczywistego) zagrożenia (np. zatrucia tlenkiem węgla) nie zauważają 
confronting the results of measurements with expert knowledge are the beginning of the decision to evacuate, sometimes even forced evacuation on the basis of a state of higher necessity [18]. By sacrificing freedom and freedom of the citizen, one protects life by forcing from a place of immediate threat to life. For example, evacuating people from an indoor pool area outside a building during the winter is not evacuation to a safe place, but beyond the place of danger to a potentially safer place under the given conditions. Such evacuation requires additional measures. When carrying out this type of evacuation, provision should be made for an external cover for the evacuated persons and a final assembly point after the evacuation inside an adjacent (safe) building or a heated means of transport (e.g. a public transport bus).

The practice of conducting an evacuation provides for a situation in which it will be impossible to carry it out. This situation has been taken into account in the legal conditions. The building must be designed in such a way as to provide for the possibility of evacuation or rescue in another way. The concept of saving in a different way hides all design solutions that will ensure people's survival in the conditions of a fire [19]. Therefore, evacuation involves the need to leave the place of danger. Saving in a different way assumes the possibility of people staying in a given evacuation zone, which ensures the possibility of their survival in fire conditions. Thus, in practice, it is possible to combine these two types of activities aimed at ensuring the safety of people [20]. The defend-in-place strategy is a strategy used among others in hospitals, prisons and places where rapid evacuation is not possible.

\section{Purpose of evacuation and criteria for assessing evacuation safety}

The purpose of evacuation is to save people, animals or property from imminent danger. The evacuation of people, animals and property is therefore an ongoing process in which there is a race between the remaining escape route and the impending threat. What is expected in this process is that the movement takes place faster or at the same rate as the spreading threat. Where the risk spreads more rapidly, there is a risk of failure of the evacuation process for some of the entities covered by it.

The second purpose of evacuation is to move in a safe way. This means that the evacuation process itself cannot pose a greater danger than the threat that causes the evacuation. A small fire on one of the last floors of a high building can be used as an example. Conducting a full evacuation of the entire building can cause a much greater danger on the escape routes than the resulting fire, which can be controlled by the fire protection devices in which the facility is equipped. However, this does not exclude the need to conduct selective evacuation, limited to the floor where the fire occurred and floors threatened by the possibility of the fire spreading. go i nie są przekonani o konieczności ewakuacji. Dopiero działania służb polegające na pomiarze stężenia tlenku węgla oraz skonfrontowania wyników pomiarów z wiedzą ekspercką są początkiem podjęcia decyzji o ewakuacji, czasami nawet ewakuacji przymusowej na zasadzie stanu wyższej konieczności [18]. Poświęcając wolność i swobodę obywatela chroni się jego życie ewakuując pod przymusem z miejsca bezpośredniego zagrożenia życia. Przykładowo ewakuacja ludzi z obszaru basenu krytego na zewnątrz budynku w okresie zimowym nie jest ewakuacją do miejsca bezpiecznego, ale poza miejsce zagrożenia do miejsca potencjalnie bezpieczniejszego w danych warunkach. Taka ewakuacja wymaga podjęcia dodatkowych działań. Podczas prowadzenia tego rodzaju ewakuacji należy przewidzieć okrycie zewnętrzne dla ewakuujących się osób oraz docelowe miejsce zbiórki po ewakuacji wewnątrz sąsiedniego (bezpiecznego) budynku lub ogrzewanego środka transportu (np. autobusu komunikacji publicznej).

Praktyka związana z prowadzeniem ewakuacji przewiduje sytuację, w której będzie brak możliwości jej prowadzenia. Taka sytuacja została uwzględniona w uwarunkowaniach prawnych. Obiekt budowlany należy tak zaprojektować, aby zapewnić możliwość ewakuacji lub uratowania w inny sposób. Pod pojęciem uratowania w inny sposób kryją się wszelkie rozwiązania projektowe, które w warunkach pożaru zapewnią ludziom jego przetrwanie [19]. Ewakuacja zatem wiąże się z koniecznością opuszczenia miejsca zagrożenia. Uratowanie w inny sposób zakłada możliwość przebywania ludzi w danej strefie ewakuacji, która zapewnia możliwość ich przetrwania w warunkach pożaru. Zatem w praktyce istnieje możliwość łączenia tych dwóch rodzajów działań mających na celu zapewnienie bezpieczeństwa ludzi [20]. Strategia obrony na miejscu (ang. defend-in-place) to strategia stosowana m.in. w szpitalach, więzieniach i miejscach, w których szybka ewakuacja jest niemożliwa.

\section{Cel ewakuacji oraz kryteria oceny bezpieczeństwa ewakuacji}

Celem prowadzenia ewakuacji jest uratowanie ludzi, zwierząt lub mienia przed grożącym niebezpieczeństwem. Ewakuacja ludzi, zwierząt i mienia jest zatem ciągłym procesem, w którym trwa wyścig pomiędzy pozostałą do pokonania drogą ewakuacyjną a zbliżającym się zagrożeniem. Oczekiwane $w$ tym procesie jest, aby przemieszczanie odbywało się szybciej lub w takim samym tempie jak rozprzestrzeniające się zagrożenie. W przypadku gdy zagrożenie rozprzestrzenia się szybciej, istnieje ryzyko niepowodzenia procesu ewakuacji dla części podmiotów nią objętych.

Drugim celem prowadzenia ewakuacji jest przemieszczanie w sposób bezpieczny. Oznacza to, że sam proces ewakuacji nie może stanowić większego niebezpieczeństwa niż zagrożenie będące przyczyną prowadzenia ewakuacji. Można się tutaj posłużyć przykładem niewielkiego pożaru na jednej z ostatnich kondygnacji budynku wysokiego. Prowadzenie ewakuacji pełnej całego budynku może spowodować powstanie znacznie większego zagrożenia na drogach ewakuacyjnych niż powstały pożar, który może być kontrolowany przez urządzenia przeciwpożarowe, w które wyposażony jest obiekt. Nie wyklucza to jednak konieczności prowadzenia ewakuacji 
As can be seen, both goals stand in some opposition to each other. On one hand, the evacuation should be carried out quickly, on the other hand - safely. In this case, it is necessary to ensure a certain optimal level, for which the evacuation rate associated with the threat and the level of safety of this process will be balanced. This issue is not simple and requires an appropriate scientific apparatus. In the future, a solution to the problem may be dynamic (adaptive) evacuation lighting systems, which will ensure optimal evacuation for a given level of danger.

The optimal level of safety of the evacuation process is inextricably linked, among others, to regular evacuation exercises, as they allow to adjust the procedures and stages of evacuation of the facility in such a way as to minimize the possibility of dangerous events [21]. Managing the evacuation process should be a vector for the development of systems supporting the organization of evacuation. In addition to dynamic evacuation lighting, the systems supporting the evacuation process also include voice alarm systems. Proper interaction of the systems is the key to conducting a more secure and at the same time relatively fast process of evacuation of the facility in the event of a threat.

Over the twentieth century, many concepts have been proposed to assess the level of safety of the process of evacuating people from objects. The concept that currently best reflects the conditions of the evacuation process in the event of a spreading emergency is to compare the required and available time of safe evacuation $[5,8]$. Required safe egress time (RSET) is the period of time from the moment a fire occurred to the moment the last person evacuating the object left the endangered facility. It takes into account the time necessary to detect a threat, alert the building users, the reactions of the building users to the alarm and the time of passage along the escape routes. Available safe egress time (ASET) is a fragment of time from the moment of fire to the occurrence of critical conditions for the evacuation process. Critical conditions in the event of a developing fire are concentrations of toxic, irritating and suffocating gases, density of thermal radiation flux and range of visibility.

$$
t_{\text {margin }}=\text { ASET-RESET }
$$

where: $t_{\text {margin }}$ - safety margin

In order for the evacuation to take place in safe conditions, the available time of safe evacuation must be greater than the required time of safe evacuation. The difference between ASET and RSET is the so-called safety margin (1). The safety margin should take into account the possibility of a possible prolongation of the evacuation process or a faster development of the fire. Legal regulations regarding the safety of the evacuation process gradually take into account the provision of an appropriate level of safety margin. For example, the Italian Fire Prevention Code (IFC) [22] sets the minimum safety margin value at $10 \%$ of the RSET but not less than 30 seconds. The ASET/RSET concept, despite its shortcomings, is currently the only one that allows a qualitative and quantitative assessment of the level of safety of the evacuation process [23]. selektywnej, ograniczonej do piętra, na którym powstał pożar oraz pięter zagrożonych możliwością rozprzestrzenienia się pożaru.

Jak łatwo zauważyć, obydwa cele stoją w pewnej opozycji w stosunku do siebie. $Z$ jednej strony ewakuacja powinna przebiegać szybko, z drugiej strony bezpiecznie. Niezbędne w tym przypadku jest zapewnienie pewnego poziomu optymalnego, dla którego tempo ewakuacji związane z zagrożeniem oraz poziom bezpieczeństwa tego procesu będą zbalansowane. Zagadnienie to nie jest proste i wymaga odpowiedniego aparatu naukowego. Rozwiązaniem zagadnienia mogą być w przyszłości systemy dynamicznego (adaptacyjnego) oświetlenia ewakuacyjnego, które zapewnią prowadzenie optymalnej ewakuacji dla danego poziomu zagrożenia.

Optymalny poziom bezpieczeństwa procesu ewakuacji nierozerwalnie związany jest $\mathrm{m}$.in. z wykonywanymi regularnie ćwiczeniami ewakuacyjnymi, gdyż pozwalają one dostosować procedury i etapy ewakuacji obiektu w taki sposób, aby zminimalizować możliwość powstania niebezpiecznych zdarzeń [21]. Kierowanie procesem ewakuacji powinno być wektorem rozwoju systemów wspomagających organizację ewakuacji. Do tych systemów należy zaliczyć oprócz dynamicznego oświetlenia ewakuacyjnego także dźwiękowe systemy ostrzegawcze. Odpowiednie ich współdziałanie jest kluczem do prowadzenia bardziej bezpiecznego, a równocześnie stosunkowo szybkiego procesu ewakuacji obiektu w przypadku powstania zagrożenia.

Na przestrzeni dwudziestego wieku zaproponowano wiele koncepcji oceny poziomu bezpieczeństwa procesu ewakuacji ludzi z obiektów. Koncepcją, która obecnie najlepiej odzwierciedla warunki procesu ewakuacji w przypadku rozprzestrzeniającego się zagrożenia, jest porównanie wymaganego oraz dostępnego czasu bezpiecznej ewakuacji $[5,8]$. Wymagany czas bezpiecznej ewakuacji RSET (ang. required safe egress time) jest to odcinek czasu od momentu powstania pożaru do chwili opuszczenia zagrożonego obiektu przez ostatnią ewakuującą się osobę. Uwzględnia on czas niezbędny na detekcję zagrożenia, alarmowanie użytkowników budynku, reakcje użytkowników budynku na wygłoszony alarm oraz czas przejścia drogami ewakuacyjnymi. Dostępny czas bezpiecznej ewakuacji ASET (ang. available safe egress time) jest to natomiast fragment czasu od chwili powstania pożaru do momentu wystąpienia warunków krytycznych dla prowadzenia procesu ewakuacji. Warunkami krytycznymi w przypadku rozwijającego się pożaru są stężenia gazów toksycznych, drażniących i duszących, gęstość strumienia promieniowania cieplnego oraz zasięg widzialności.

$$
t_{\text {margin }}=\text { ASET-RESET }
$$

gdzie: $t_{\text {margin }}-$ margines bezpieczeństwa

Aby ewakuacja przebiegała w bezpiecznych warunkach dostępny czas bezpiecznej ewakuacji musi być większy od wymaganego czasu bezpiecznej ewakuacji. Różnica pomiędzy ASET i RSET jest tzw. marginesem bezpieczeństwa (1). Margines bezpieczeństwa powinien uwzględniać możliwość ewentualnego przedłużenia się procesu ewakuacji lub szybszego rozwoju pożaru. Regulacje prawne dotyczące bezpieczeństwa procesu ewakuacji stopniowo uwzględniają zapewnienie odpowiedniego poziomu marginesu bezpieczeństwa. Na przykład we włoskich przepisach przeciwpożarowych (ang. Italian Fire Prevention Code, IFC) [22] określono minimalną wartość marginesu bezpieczeństwa jako 10\% RSET lecz nie mniej niż 30 sekund. Obecnie koncepcja ASET/RSET 
pomimo wad jest jedyną pozwalającą w sposób jakościowy i ilościowy na ocenę poziomu bezpieczeństwa procesu ewakuacji [23].

\section{Różnorodność określeń procesu ewakuacji w publikacjach}

\section{Variety of definitions of the evacuation process in publications}

In the literature on the subject there are many adjectives characterizing the concept of evacuation and defining its types. One of the terms is gradual evacuation [24]. A gradual evacuation is a type of an evacuation process in which people from different places in a building are evacuated in a specific order (first people from places affected by the fire, and then from the rest of the facility) [25]. The dictionary of the Polish language defines a gradual adjective as having a slow course - e.g. a gradual increase in temperature. A more precise term for an evacuation consisting of evacuation in a specific order would be sequential evacuation. The adjective sequential [26] is characteristic of the arrangement of some elements in which they appear in a strictly defined order. The concept of sequential evacuation is introduced by M. Smolarkiewicz [27]: "The crisis manager has the possibility of only sequential evacuation of both objects (i.e. one by one)".

The concept of sequential evacuation was introduced in foreign literature among others in an article Calculating evacuation times for tall buildings [28].

Another concept found in the literature on the subject is selective evacuation [28], which consists in providing a fire alarm on different floors with appropriate time intervals so that vertical escape routes do not form queues of people waiting to leave [29]. In the Dictionary of the Polish Language [26], the term selective is defined as "covering only some elements of the whole" so selective evacuation is one that covers only a selected part of the object and that does not take into account the possibility of the occurrence of stages of its implementation.

In turn, P. Gromek introduces a division of evacuation into general and phase evacuation [30]. "In the facilities of educational institutions with systems of escape routes generating the formation of so-called bottlenecks, it is possible to diversify the forms of evacuation into general evacuation and phase evacuation. The former deals with the simultaneous emptying of the facility after the alarm is announced for all its users. In the second case, account shall be taken of the differentiation of the order in which the various groups in the danger zone leave the danger zone in order to maintain the patency of the escape routes". The common adjective refers to all things, people, matters, etc. [26]. Its synonym can be full. In the sense of a full evacuation, it will be one in which nothing is missing, which constitutes a whole [26]. Phase evacuation fits into the already discussed definition of sequential evacuation. The interchangeable use of phase and sequential evacuation adjectives also occurs in foreign literature [31-32]. The phase adjective is a definition of the state of the phenomenon at a given moment rather than an evacuation carried out in an appropriate sequence [26]. Of course, in the evacuation process we can talk about phases, but nevertheless these phases will concern the characteristics of this process regardless of its scope.
W literaturze przedmiotu występuje wiele przymiotników charakteryzujących pojęcie ewakuacji oraz określających jej rodzaje. Jednym z określeń jest ewakuacja stopniowa [24]. Jest to rodzaj prowadzenia procesu ewakuacji, $w$ którym ludzie $z$ różnych miejsc w obiekcie budowlanym są ewakuowani w określonej kolejności (na początku ludzie z miejsc objętych pożarem, a następnie z pozostałej części obiektu) [25]. Słownik języka polskiego definiuje przymiotnik stopniowy jako mający powolny przebieg - np. stopniowy wzrost temperatury. Bardziej precyzyjnym określeniem ewakuacji polegającej na ewakuowaniu w określonej kolejności byłaby ewakuacja sekwencyjna. Przymiotnik sekwencyjny [26] charakterystyczny jest dla układu jakichś elementów, w których występują one w ściśle określonej kolejności. Pojęcie ewakuacji sekwencyjnej wprowadza M. Smolarkiewicz [27]: „Zarządzający sytuacją kryzysową ma możliwość jedynie sekwencyjnej ewakuacji obu obiektów (tzn. jeden po drugim)".

Pojęcie ewakuacji sekwencyjnej wprowadzone zostało w literaturze zagranicznej m.in. w artykule pt. Calculating evacuation times for tall buildings [28].

Innym pojęciem występującym w literaturze przedmiotu jest ewakuacja selektywna [28] polegająca na podaniu alarmu pożarowego na różnych kondygnacjach z odpowiednimi odstępami czasowymi tak, aby na pionowych drogach ewakuacji nie tworzyły się kolejki osób oczekujących na wyjście [29]. W Słowniku języka polskiego [26] termin selektywny definiowany jest jako "obejmujący tylko niektóre elementy całości", a więc ewakuacja selektywna to taka, którą objęta jest jedynie wybrana część obiektu i która nie uwzględnia możliwości występowania etapów jej realizacji.

Z kolei P. Gromek wprowadza podział ewakuacji na ewakuację powszechną oraz fazową [30]. „W obiektach placówek oświatowych o układach dróg ewakuacji generujących powstawanie tzw. wąskich gardeł istnieje możliwość dywersyfikacji form ewakuacji na ewakuację powszechną oraz ewakuację fazową. Ta pierwsza traktuje o równoczesnym opróżnianiu placówki po ogłoszeniu alarmu dla wszystkich jej użytkowników. W drugim przypadku bierze się pod uwagę zróżnicowanie kolejności opuszczania strefy zagrożenia przez poszczególne grupy się w niej znajdujące tak, aby zachować drożność dróg ewakuacji". Przymiotnik powszechny dotyczy wszystkich rzeczy, osób, spraw, itp. [26]. Jego synonimem może być pełny. W znaczeniu pełna ewakuacja będzie to taka, w której niczego nie brakuje, która stanowi całość [26]. Ewakuacja fazowa wpisuje się w omawianą już definicję ewakuacji sekwencyjnej. Wymienne stosowanie przymiotników ewakuacji fazowej oraz sekwencyjnej występuje również w literaturze zagranicznej [31-32]. Przymiotnik fazowy jest określeniem bardziej stanu zjawiska w danej chwili niż ewakuacji prowadzonej w odpowiedniej sekwencji [26]. Oczywiście w procesie ewakuacji możemy mówić o fazach, niemniej jednak fazy te będą dotyczyły charakterystyki tego procesu niezależnie od jej zakresu. 
The extent to which an evacuation covers a given facility may be the reason for its division into full or partial [33]: "In most cases, the commander of the called fire brigade unit takes command of the rescue operation and orders full or partial evacuation of a facility".

The concept of partial evacuation indicates a part of the object that has not been fully determined. A more appropriate term, according to the author, as already mentioned above, would be selective evacuation. The selection of a given part to be evacuated is the result of selection, decision-making process within the framework of knowledge and information about the developing threat by persons responsible for organizing rescue operations.

The division of the evacuation process into two types is made in the doctoral dissertation by B. Juras [34]. Evacuation, in this case of a hospital, is divided into total and partial. Total evacuation means leaving the entire hospital (the entire building) and taking all people to a safe, pre-designated place, the so-called collection point. Partial evacuation, on the other hand, is the evacuation of all people from one part of the hospital, e.g. from one wing to another [34]. In this case, partial evacuation can also take the form of on-site defence if it takes place in a fire-separated space rather than an independent fire zone. The division of evacuation into total and partial also occurs in foreign literature [35].

There is also another meaning of full evacuation in literature [36]: "When designing, it is necessary to provide early warning of a fire. The fire detection and the alarm system must provide a warning early enough to allow full evacuation from the danger zone before conditions become unacceptable". Full evacuation is presented here in such a way that all users of a facility must evacuate before critical conditions become unacceptable, threatening human lives. The authors [36], when formulating the term full evacuation, meant the success of this process. The situation of success of the evacuation process can be defined as an effective or successful evacuation [37].

Recognizing threats provides the opportunity to plan possible actions to limit their impact on people, animals and property. Evacuation planning together with evacuation exercises gives the possibility of conducting an organized evacuation [38]. Mass evacuation of the population may take the form of an organised evacuation, initiated by public administration bodies, carried out on the basis of the resources of representatives of that administration [39].

The process of movement of people can be initiated by the occurring threat regardless of the decisions made by the facility manager or people conducting the rescue operation. This form of evacuation has been defined as self-evacuation and applies only to the population. Self-evacuation consists in the movement of people from areas where there may be or has been an immediate threat to life and health outside the danger zone. It is conducted primarily on the basis of own capabilities (transport, accommodation, etc.) $[11,40]$. Self-evacuation, otherwise, is a movement according to one's own transport and accommodation capabilities [41]. It can take an organized or spontaneous form [39, 41]. Otherwise, self-evacuation can be defined as an independent evacuation, carried out without anyone's help and/or influence, regardless of other activities and processes taking place in the facility or on the premises [42].
Zakres, jakim ewakuacja obejmuje dany obiekt, może być powodem jej podziału na pełną lub częściową [33]: „W większości przypadków dowódca wezwanej jednostki straży pożarnej przejmuje dowodzenie akcją ratunkową i zarządza pełną lub częściową ewakuację obiektu".

Pojęcie częściowa ewakuacja wskazuje na część obiektu, która nie do końca została określona. Właściwszym określeniem, wg autora, jak już wspomniano powyżej, byłaby ewakuacja selektywna. Wybór danej części przeznaczonej do ewakuacji jest wynikiem selekcji, procesu podejmowania decyzji w ramach posiadanej wiedzy i informacji o rozwijającym się zagrożeniu przez osoby odpowiedzialne za organizowanie działań ratowniczych.

Podział procesu ewakuacji na dwa rodzaje dokonuje w swojej rozprawie doktorskiej B. Juras [34]. Ewakuacja, w tym przypadku szpitala, dzieli się na całkowitą i częściową. Ewakuacja całkowita to opuszczenie całego szpitala (całego budynku) i wyprowadzenie wszystkich osób do miejsca bezpiecznego, wcześniej wyznaczonego, tzw. punktu zbiórki. Natomiast ewakuacja częściowa to ewakuowanie wszystkich osób z jednej części szpitala, np. z jednego skrzydła do innego [34]. W tym przypadku ewakuacja częściowa może mieć również formę obrony na miejscu, jeśli odbywa się do przestrzeni wydzielonej przeciwpożarowo, a nie niezależnej strefy pożarowej. Podział ewakuacji na całkowitą i częściową występuje również w literaturze zagranicznej [35].

W literaturze przedmiotu występuje także inne znaczenie ewakuacji pełnej [36]: „Przy projektowaniu konieczne jest zapewnienie wczesnego ostrzegania o pożarze. Wykrycie pożaru i system alarmowy muszą zapewnić ostrzeżenie na tyle wcześnie, aby możliwa była pełna ewakuacja ze strefy zagrożenia, zanim warunki staną się nieakceptowalne". Ewakuacja pełna przedstawiana jest tu w taki sposób, że wszyscy użytkownicy obiektu muszą ewakuować się, zanim warunki krytyczne staną się nieakceptowalne, zagrażające życiu ludzi. Autorzy [36] formułując określenie ewakuacji pełnej, mieli na myśli powodzenie tego procesu. Sytuacja powodzenia procesu ewakuacji może zostać określona jako ewakuacja pomyślna lub udana [37].

Rozpoznawanie zagrożeń daje możliwość zaplanowania ewentualnych działań ograniczających ich wpływ zarówno na ludzi, zwierzęta, jak i mienie. Planowanie ewakuacji wraz z prowadzeniem ćwiczeń ewakuacyjnych daje możliwość prowadzenia ewakuacji zorganizowanej [38]. Masowa ewakuacja ludności może przybierać formę ewakuacji zorganizowanej, inicjowanej przez organy administracji publicznej, prowadzonej w oparciu o zasoby przedstawicieli tejże administracji [39].

Proces przemieszczania się ludzi może być zainicjowany przez występujące zagrożenie niezależnie od decyzji podejmowanych przez zarządcę obiektu czy osoby prowadzące akcję ratowniczą. Taka forma ewakuacji została zdefiniowana jako samoewakuacja i dotyczy wyłącznie ludności. Samoewakuacja polega na przemieszczeniu się ludności z rejonów, w których może wystąpić lub wystąpiło bezpośrednie zagrożenie dla życia i zdrowia poza strefę zagrożenia. Prowadzona jest przede wszystkim w oparciu o własne możliwości (transportowe, zakwaterowania, itd.) [11,40]. Samoewakuacja inaczej to przemieszczenie według własnych możliwości transportowych i kwaterunkowych [41]. Może ona przyjąć formę zorganizowanej lub spontanicznej [39, 41]. Inaczej samoewakuację 
Among the different types of evacuation, preventive evacuation can be distinguished [43]. It is a process of moving people, animals or property from areas or objects in the event of an impending threat. During natural disasters, e.g. floods, both preventive and rescue evacuations are carried out [44]. Preventive evacuation of facilities concerns its technical preparation for independent abandonment by people or with the help of firefighters or representatives of cooperating entities [45]. Another term for rescue evacuation in literature is intervention evacuation [45-48]. Rescue or intervention evacuation is an evacuation carried out by the rescue services arriving at the place. It aims to save people, animals or property from the imminent, often spreading threat.

In case of long-term rescue operations sometimes covering a large area, e.g. during floods, it is not possible to quickly return the population to their place of residence. Therefore, after the stage of primary evacuation, aimed at transporting or taking people out of the place of danger to a safe place, the so-called secondary evacuation consisting in delivering the population to places of temporary residence is carried out [49]. The definition of secondary evacuation may be debatable here. Moving people from a place that is already safe to a place of longer stay is not entirely an evacuation. Of course, one can use here the threat to the dignified functioning of a given group of people, which can be significantly reduced without ensuring the fulfilment of the basic needs (places of accommodation, food, personal hygiene, etc.). The above division may also apply to a form of evacuation in which, due to the rate of the development of the hazard, primary evacuation is carried out to a potentially safer place providing minimum conditions for survival, and then, under less pressure from the elapsing time, secondary evacuation to a safe place.

Due to the conditions related to the type and scale of the threat, evacuation of I, II and III degrees can be distinguished [11]. Evacuation of the first degree consists in the immediate movement of people, animals, property from areas, places where there was a sudden, unforeseen immediate threat outside the danger zone. It is implemented immediately after the threat to life, health and property. First-degree evacuation has the character of rescue (intervention) evacuation. Second-degree evacuation consists in a previously prepared planned movement of people, animals, property from areas adjacent to plants, hydrotechnical facilities, flood zones and areas adjacent to other facilities posing a potential threat to humans, animals or property in the event of damage or failure. It is implemented in the event of symptoms of such a threat. Second-degree evacuation is mainly a preventive, planned and organized evacuation. Evacuation of the third degree consists in the previously prepared movement of population, animals, property while increasing the state of defence readiness of the state. It is conducted at a time of threat to state security and war. Like the second stage evacuation, it is a planned and organized evacuation, carried out in an exceptional situation covering a large area of the country.

The development of fire protection devices, including dynamic evacuation lighting systems, allows for another division into managed (guided) and unmanaged evacuation. In the można określić jako ewakuację samodzielną, realizowaną bez niczyjej pomocy i/lub wpływu, niezależnie od innych działań i procesów zachodzących w obiekcie lub na terenie [42].

Spośród różnych rodzajów ewakuacji wyróżnić można ewakuację prewencyjną [43]. Jest to proces przemieszczania ludzi, zwierząt lub mienia z terenów lub obiektów w przypadku zbliżającego się zagrożenia. Podczas katastrof naturalnych, np. powodzi, prowadzona jest zarówno ewakuacja prewencyjna, jak i ratownicza [44]. Ewakuacja prewencyjna obiektów dotyczy jego przygotowania pod względem technicznym do samodzielnego opuszczenia przez ludzi bądź przy pomocy strażaków lub przedstawicieli podmiotów współdziałających [45]. Innym określeniem ewakuacji ratowniczej w literaturze przedmiotu jest ewakuacja interwencyjna [45-48]. Ewakuacja ratownicza czy inaczej interwencyjna jest ewakuacją realizowaną przez przybyłe na miejsce służby ratownicze. Ma ona na celu uratowanie ludzi, zwierząt lub mienia przed grożącym im bezpośrednim, często rozprzestrzeniającym się zagrożeniem.

W przypadku długotrwałych działań ratowniczych obejmujących niekiedy znaczny obszar np. podczas powodzi, nie ma możliwości szybkiego powrotu ludności do swojego miejsca zamieszkania. W związku z powyższym po etapie ewakuacji pierwotnej, mającej na celu wywiezienie lub wyprowadzenie ludzi z miejsca zagrożenia do miejsca bezpiecznego, prowadzi się tzw. ewakuację wtórną polegającą na dostarczeniu ludności do miejsc tymczasowego przebywania [49]. Dyskusyjne może być w tym miejscu określenie ewakuacji wtórnej. Przemieszczanie ludzi z miejsca już bezpiecznego do miejsca dłuższego przebywania nie do końca ma charakter ewakuacji. Oczywiście można tutaj posiłkować się zagrożeniem dla godnego funkcjonowania danej grupy ludzi, które może być znacznie ograniczone bez zapewnienia realizacji podstawowych potrzeb (miejsca nocowania, wyżywienia, higieny osobistej, itp.). Powyższy podział może odnosić się również do takiej formy ewakuacji, w której to w związku z tempem rozwoju zagrożenia prowadzi się ewakuację pierwotną do miejsca potencjalnie bezpieczniejszego zapewniającego minimalne warunki do przetrwania, a następnie już pod mniejszą presją upływającego czasu, ewakuację wtórną do miejsca bezpiecznego.

Z uwagi na uwarunkowania związane z rodzajem i skalą zagrożenia można wyróżnić ewakuację I, II i III stopnia [11]. Ewakuacja I stopnia polega na niezwłocznym przemieszczaniu poza strefę zagrożenia ludności, zwierząt, mienia z obszarów, miejsc, w których wystąpiło nagłe, nieprzewidzialne bezpośrednie zagrożenie. Realizuje się ją natychmiast po zaistnieniu zagrożenia życia, zdrowia i mienia. Ewakuacja I stopnia ma charakter ewakuacji ratowniczej (interwencyjnej). Ewakuacja II stopnia polega na uprzednio przygotowanym planowym przemieszczaniu ludności, zwierząt, mienia z rejonów przyległych do zakładów, obiektów hydrotechnicznych, ze stref zalewowych oraz rejonów przyległych do innych obiektów stanowiących potencjalne zagrożenie dla ludzi, zwierząt lub mienia w przypadku uszkodzenia lub awarii. Realizuje się ją w sytuacji wystąpienia symptomów takiego zagrożenia. Ewakuacja II stopnia ma głównie charakter ewakuacji prewencyjnej, planowanej oraz zorganizowanej. Ewakuacja III stopnia polega na uprzednio przygotowanym przemieszczaniu ludności, zwierząt, mienia podczas podwyższania stanu gotowości obronnej państwa. Prowadzona 
first case, the directions and escape routes shall be determined before the fire alarm is sounded and, if necessary, corrected during the evacuation. In the second case, the facility has a functioning system of permanent evacuation marking, which is the same for each scenario of the development of events in the facility. Currently, devices are being developed and introduced to support and manage the evacuation process in buildings, mainly multi-family residential buildings. In connection with the fire in London's Grenfell Tower building, the BS 8629:2019 standard [6] was developed. This standard aims to provide a reliable and effective tool to support the evacuation process of a building intended for rescue teams.

Analysing the variety of terms of the evacuation process, it is impossible to omit the trial evacuation [33,50-51]. In the absence of danger, it is difficult to talk about conducting the evacuation process. Evacuation exercises would be a more appropriate term [52-53]. This formulation is also supported by legal provisions that define evacuation exercises as a practical check of the organization and conditions of evacuation [54].

Given the different nature of evacuation exercises from evacuation, it is appropriate to introduce a definition of this type of process. According to the authors, an evacuation test (evacuation exercises) is an orderly movement of people from a place defined as dangerous to a place designated as safe, carried out in the form of exercises without a real threat to human life and health.

\section{Classification of the evacuation process}

The evacuation process can be divided according to the object from which it is carried out:

- evacuation from the area,

- evacuation from the means of transport,

- evacuation of the building,

- evacuation of the battlefield (currently in Afghanistan).

Evacuation of the area may concern the occurrence of a natural disaster, but also the area of a mass event. A natural disaster can cover a certain area that people inhabit. Moving a significant number of people with their belongings is an organizational and logistical challenge. In this case, multiple safe places should be designated to for the evacuated, as there may not be enough resources in one place to provide adequate shelter for all evacuees. In case of mass events, the zones of greatest danger are places within the stage or in the areas of ticket zones and at the entrances to the event area. In both cases, a certain degree of dispersion of the evacuees is indicated. In a situation of this type of evacuation, it is necessary to define several directions jest w czasie zagrożenia bezpieczeństwa państwa i wojny. Tak jak ewakuacja II stopnia jest ona ewakuacją planowaną i zorganizowaną, realizowaną w wyjątkowej sytuacji obejmującej duży obszar państwa.

Rozwój urządzeń przeciwpożarowych, w tym dynamicznych systemów oświetlenia ewakuacyjnego, pozwala na dokonanie jeszcze jednego podziału na ewakuację zarządzaną (kierowaną) oraz niezarządzaną. W pierwszym przypadku kierunki i drogi ewakuacji są określane przed ogłoszeniem alarmu pożarowego oraz w przypadku konieczności korygowane podczas prowadzenia ewakuacji. W drugim przypadku w obiekcie funkcjonuje system stałego oznakowania ewakuacyjnego, które jest takie samo dla każdego scenariusza rozwoju zdarzeń w obiekcie. Obecnie powstają oraz są wprowadzane urządzenia, których celem jest wspomaganie oraz zarządzanie procesem ewakuacji w budynkach, głównie mieszkalnych wielorodzinnych. W związku z pożarem w londyńskim budynku Grenfell Tower opracowano normę BS 8629:2019 [6]. Norma ta ma na celu dostarczenie niezawodnego i skutecznego narzędzia wspomagającego proces ewakuacji budynku przeznaczonego dla ekip ratowniczych.

Analizując różnorodność określeń procesu ewakuacji, nie sposób pominąć ewakuacji próbnej [33,50-51]. W sytuacji braku zagrożenia trudno mówić o prowadzeniu procesu ewakuacji. Właściwszym określeniem byłyby ćwiczenia ewakuacyjne [52-53]. Za takim sformułowaniem przemawiają również przepisy prawa, które określają ćwiczenia ewakuacyjne jako praktyczne sprawdzenie organizacji oraz warunków ewakuacji [54].

Mając na uwadze odmienny charakter ćwiczeń ewakuacyjnych od ewakuacji właściwe jest wprowadzenie definicji tego rodzaju procesu. Według autorów próba ewakuacyjna (ćwiczenia ewakuacyjne) to uporządkowany ruch ludzi z miejsca określonego jako niebezpieczne do miejsca wyznaczonego jako bezpieczne, realizowane $w$ formie ćwiczeń bez realnego zagrożenia dla życia i zdrowia ludzi.

\section{Klasyfikacji procesu ewakuacji}

Proces ewakuacji można podzielić ze względu na rodzaj obiektu, z którego jest ona prowadzona:

- ewakuacja z obszaru,

- ewakuacja ze środka transportu,

- ewakuacja obiektu budowlanego,

- ewakuacja pola walki (obecnie w Afganistanie).

Ewakuacja obszaru może dotyczyć występowania klęski żywiołowej, ale także terenu imprezy masowej. Klęska żywiołowa może objąć pewien obszar, który zamieszkują ludzie. Przemieszczenie znacznej liczby osób wraz z ich dobytkiem jest wyzwaniem organizacyjnym i logistycznym. W takim przypadku należy wyznaczyć wiele miejsc bezpiecznych, do których prowadzona będzie ewakuacja, gdyż w jednym miejscu może nie być wystarczającej liczby środków do zapewnienia odpowiedniego schronienia dla wszystkich ewakuowanych. W przypadku imprez masowych strefami największego zagrożenia są miejsca w obrębie sceny lub w obszarach stref biletowych oraz przy wejściach na teren imprezy. Zarówno w jednym, jak i w drugim przypadku 
of evacuation in such a way as to effectively deploy people and remove them from the place of danger and without causing other additional hazards that may be caused by the concentration of people in only one place. Evacuation from such facilities is specific due to the limited width of passages and exits.

A very large undertaking is the evacuation of an aircraft (airplane), because the development of the threat is usually very fast (available time of safe evacuation - short), and the possibility of evacuation is usually limited by a certain number of emergency exits. The number of people on board the aircraft is significant and can be counted up to hundreds. The experience of the cabin crew and their decisive actions often determine the success of the evacuation process.

Evacuation of a building object is the most well-known type of evacuation. In buildings we stay most of our lives. Everyone at least once took part in an evacuation exercise.

Battlefield evacuation is a specific type of evacuation, in many respects similar to the evacuation of an area in the event of a natural disaster. Division of this type of evacuation due to the time of occurrence of the threat:

- preventive - the threat will occur in a relatively short time (evacuation can be prepared and planned),

- rescue, intervention - the threat is present.

When designing objects intended for people, it is necessary to ensure appropriate evacuation conditions in them. These buildings must be designed and planned taking into account applicable laws, standards and technical knowledge. With this in mind, the investor at the stage of designing the investment should analyse the evacuation process in the event of a threat of the so-called preventive evacuation.

Preventive evacuation also takes place in the event of foreseeable natural disasters. Such a disaster is even a flood. Rising water in rivers and a moving flood wave is a signal for emergency management services to take remedial action. In a situation of a real threat of flooding of specific areas, including residential or industrial areas occupied by man, evacuation activities are carried out in advance to save not only human life and health, but also the lives of animals and property from flooding.

However, even in the best designed building, there may be conditions that make evacuation difficult or impossible. Such a threat may be, for example, a fire caused by terrorist activities. We had a drastic example of this during the terrorist attacks on the World Trade Centre on September 11, 2001. Despite the design of the facility for the so-called preventive evacuation, the actions of the terrorists led to making evacuation on the floors below the fire site more difficult and preventing it above the fire site.

In the event of cutting off or hindering the way of moving along escape routes, there is a real possibility of saving people. However, this circumstance occurs only with the use of specialized equipment and the skills and knowledge of the rescuers. Evacuation carried out by means of ladders, lifts or leading out users of the facility along smoky escape routes in rescue air apparatus is an intervention or rescue evacuation. It is an extremely difficult evacuation, depending on the degree of fire development (threat) and the forces and resources available on wskazany jest pewien stopień rozproszenia ewakuowanych osób. W sytuacji tego rodzaju ewakuacji niezbędne jest określenie kilku kierunków ewakuacji w taki sposób, aby skutecznie rozlokować ludzi i usunąć ich z miejsca zagrożenia oraz nie powodując dodatkowych innych zagrożeń, jakie mogą zostać wywołane przez koncentrację ludzi w tylko jednym miejscu. Ewakuacja z tego rodzaju obiektów jest specyficzna ze względu na ograniczoną szerokość przejść oraz wyjść.

Bardzo dużym przedsięwzięciem jest ewakuacja statków powietrznych (samolotów), gdyż rozwój zagrożenia przeważnie jest bardzo szybki (dostępny czas bezpiecznej ewakuacji - krótki), a możliwość ewakuacji jest przeważnie ograniczona przez określoną liczbę wyjść ewakuacyjnych. Liczba osób przebywających na pokładzie statku powietrznego jest znaczna i można ją liczyć nawet w setkach. Doświadczenie personelu pokładowego oraz ich zdecydowane działania niejednokrotnie przesądzają o powodzeniu procesu ewakuacji.

Ewakuacja obiektu budowlanego jest to najbardziej znany rodzaj ewakuacji. W obiektach budowlanych przebywamy większą część naszego życia. Każdy człowiek spotkał się chociażby raz z ćwiczeniami ewakuacyjnymi.

Ewakuacja pola walki jest specyficznym rodzajem ewakuacji podobnym pod wieloma względami do ewakuacji obszaru w przypadku klęski żywiołowej. Podział tego typu ewakuacji ze względu na czas występowania zagrożenia:

- prewencyjna - zagrożenie wystąpi w stosunkowo krótkim czasie (ewakuacja może zostać przygotowana i zaplanowana),

- ratownicza, interwencyjna - zagrożenie występuje aktualnie.

Projektując obiekty przeznaczone dla ludzi, niezbędne jest zapewnienie w nich odpowiednich warunków ewakuacji. Budynki te muszą być projektowane oraz planowane $z$ uwzględnieniem obowiązujących przepisów prawa, norm oraz wiedzy technicznej. Mając to na uwadze, inwestor na etapie projektowania inwestycji powinien przeanalizować proces ewakuacji na wypadek wystąpienia zagrożenia tzw. ewakuacji prewencyjnej.

Ewakuacja prewencyjna ma również miejsce w przypadku klęsk żywiołowych możliwych do przewidzenia. Taką klęską jest chociażby powódź. Wzbierająca woda w rzekach oraz przemieszczająca się fala wezbraniowa jest sygnałem dla służb zarządzania kryzysowego do podjęcia działań zaradczych. W sytuacji realnego zagrożenia zalaniem określonych terenów, w tym zajmowanych przez człowieka terenów mieszkalnych lub przemysłowych, prowadzi się z wyprzedzeniem działania ewakuacyjne mające na celu uratowanie nie tylko życia i zdrowia ludzi, ale także życia zwierząt i mienia przed zalaniem.

Nawet w najlepiej zaprojektowanym budynku mogą jednak zaistnieć warunki utrudniające lub uniemożliwiające ewakuację. Takim zagrożeniem może być chociażby pożar spowodowany działaniem terrorystycznym. Drastyczny tego przykład mieliśmy podczas zamachów terrorystycznych na World Trade Center 11 września 2001 r. Pomimo zaprojektowania obiektu na tzw. ewakuację prewencyjną, działanie terrorystów doprowadziło do utrudnienia ewakuacji na kondygnacjach poniżej miejsca pożaru oraz uniemożliwienia jej powyżej miejsca pożaru. 
the spot. Undoubtedly, it can be said that in the absence of appropriate equipment, forces and resources, the possibility of survival of imprisoned people drops drastically to zero. An example of a tragic incident involving the cutting off of the escape route is the fire of a shopping centre in Giżycko on March 5,2008 , in which two women were killed. Despite the rescue efforts involving rescuers taking two women out of the burning building, they could not be saved. The rapid development of the fire and the formation of a large amount of hot and toxic smoke caused fatal poisoning of the employees of the shopping centre.

Division of the evacuation due to the scope of the facility's coverage:

- total,

- selective.

The occurrence of a hazardous event requires the determination of the space that is directly or indirectly threatened. A fire created in a building may endanger people in the fire zone in which it occurs. Developed fires, the duration of which is similar to the time when the elements of fire separations perform their protective function, will pose a real threat to the neighbouring fire zones. However, in the case of fires lasting approximately as long as the bearing capacity of the main structure, there is a risk of loss of life and health by its users and this will apply to the entire facility, which often consists of many fire zones.

At the stage of deciding on the scope and method of evacuation, it is necessary to determine whether the entire facility or only part of it will be evacuated. As a consequence of the evacuation of the entire facility, we can talk about a complete evacuation. However, if the conditions in a building allow for the evacuation of only a selected part of it, then we can talk about selective evacuation. It may include several fire zones in the facility, but will not lead to the evacuation of all its users. This solution also applies if the evacuation of the entire facility would pose a greater risk than the fire itself, the extinguishing of which by the building staff or the services arriving at the site will end faster than the evacuation process of the building.

Division of the evacuation due to the time of its commencement by individual users of the facility.

- simultaneous,

- sequence.

The decision to evacuate the entire building is very difficult to make. A person deciding to introduce the obligation of total evacuation should have very good knowledge both in terms of evacuation, architectural and construction conditions, fire protection devices, as well as evacuation conditions in the facility. In order to limit the effects of dangerous events involving people during evacuation, it is possible to spread the alarm of the individual fire (alarm) zones over time. Such a procedure is aimed at preventing the formation of congestion on the escape routes, which significantly slow down the evacuation process itself, and sometimes may even lead to its complete stop. Alarming individual parts of the building performed in a specific sequence is conducting evacuation in a sequential manner. In the absence of sequence, we are talking about simultaneous evacuation. It is possible mainly in single-storey buildings with simple architecture and with many emergency exits. In the case of all multi-storey buildings,
W sytuacji odcięcia lub utrudnienia sposobu przemieszczania się drogami ewakuacyjnymi istnieje realna możliwość uratowania ludzi. Niemniej jednak okoliczność ta zachodzi jedynie przy wykorzystaniu specjalistycznego sprzętu oraz umiejętności i wiedzy ratowników. Ewakuacja prowadzona za pomocą drabin, podnośników czy wyprowadzanie użytkowników obiektu zadymionymi drogami ewakuacyjnymi w ratunkowych aparatach powietrznych jest ewakuacją interwencyjną lub inaczej ratowniczą. Jest to ewakuacja niezwykle trudna, uzależniona od stopnia rozwoju pożaru (zagrożenia) oraz dostępnych na miejscu sił i środków. Bez wątpienia można stwierdzić, że w przypadku braku odpowiedniego sprzętu oraz sił i środków możliwość przeżycia uwięzionych osób spada drastycznie do zera. Przykładem tragicznego zdarzenia polegającego na odcięciu drogi ewakuacyjnej jest pożar centrum handlowego w Giżycku 5 marca 2008 r., w którym śmierć poniosły dwie kobiety. Pomimo działań ratowniczych polegających na wyniesieniu przez ratowników z płonącego budynku dwóch kobiet nie udało się ich uratować. Szybki rozwój pożaru oraz powstanie dużej ilości gorącego i toksycznego dymu spowodowały śmiertelne zatrucie pracownic centrum handlowego.

Podział ewakuacji ze względu na zakres objęcia nią obiektu:

- całkowita,

- selektywna.

Wystąpienie zagrożenia niebezpiecznego wymaga określenia przestrzeni, która jest zagrożona bezpośrednio lub pośrednio. Powstały w budynku pożar może zagrażać osobom znajdującym się w strefie pożarowej, w której występuje. Pożary rozwinięte, których czas trwania jest zbliżony do czasu, w którym elementy oddzieleń przeciwpożarowych spełniają swoją funkcję ochronną, będą stanowiły realne zagrożenie dla sąsiadujących stref pożarowych. Natomiast w przypadku pożarów trwających w przybliżeniu tyle co czas nośności głównej konstrukcji istnieje ryzyko utraty życia i zdrowia przez jej użytkowników. Będzie dotyczyło to całego obiektu składającego się niejednokrotnie z wielu stref pożarowych.

$\mathrm{Na}$ etapie decydowania o zakresie i sposobie ewakuacji niezbędne jest określenie, czy ewakuowany będzie cały obiekt, czy tylko jego część. W konsekwencji ewakuacji całego obiektu możemy mówić o ewakuacji całkowitej. Natomiast jeśli warunki występujące w budynku pozwalają na ewakuację tylko wybranej jej części, to możemy mówić o ewakuacji selektywnej. Może ona obejmować kilka stref pożarowych w obiekcie, ale nie będzie prowadzić do ewakuacji wszystkich jego użytkowników. Takie rozwiązanie ma zastosowanie również wtedy, gdy ewakuacja całego obiektu stwarzałaby większe zagrożenie niż sam pożar, którego ugaszenie przez personel budynku lub przybyłe na miejsce służby zakończy się szybciej niż proces ewakuacji budynku.

Podział ewakuacji ze względu na czas jej rozpoczęcia przez poszczególnych użytkowników obiektu:

- równoczesna,

- sekwencyjna.

Decyzja o ewakuacji całego budynku jest bardzo trudna do podjęcia. Osoba decydująca o wprowadzeniu obowiązku ewakuacji całkowitej powinna posiadać bardzo dobrą wiedzę zarówno w zakresie prowadzenia ewakuacji, uwarunkowań architektoniczno-budowlanych, występujących urządzeń przeciwpożarowych, jak i warunków ewakuacji w obiekcie. W celu ograniczenia skutków 
especially with one or two staircases, it is necessary to spread the alarm of individual fire zones over time so as not to create an additional threat on the staircases.

Division of the evacuation due to the person deciding to start the evacuation

- self-evacuation - the user of the object, as a result of noticing a threat, decides to evacuate,

- owner, building manager,

- emergency services,

- local government authorities,

- organs of government authority,

- president of the country.

The decision to evacuate can be made at different levels. If a hazard arises directly in the human environment, he/she may decide to eliminate the threat or to evacuate, if in his/her opinion this threat is unmanageable. Evacuation carried out by decision of a single user of a building will be the so-called self-evacuation. In particular, it takes place in facilities where there is no fire notification system, e.g. multi-family residential buildings.

The threat may develop outside the place of residence of the users of the building, and knowledge in this area may be possessed by its owner or manager. Taking care of the safety of the users of such a facility is their responsibility to order evacuation. It may also happen that the evacuation is managed by the emergency services arriving on the spot based on specialist knowledge and possible directions of threat development.

All kinds of natural disasters often require evacuation by persons representing local government authorities (head of a mayor, prefect of a district) or government (voivode, prime minister). The last body that can decide to evacuate, mainly as the head of the armed forces in the event of a threat related to the defence of the country, is the president.

Division of evacuation due to the effectiveness of the evacuation process:

- evacuation successful, beneficial, comprehensive, complete

- partial evacuation - failure of evacuation, unsuccessful evacuation.

This division is closely related to the purpose for which the evacuation process is carried out. This goal is for all persons in it to leave the danger zone. If, for some reason, this goal is not achieved, and people remain in the danger zone and are exposed to its dangerous factors, we can talk about a partial evacuation or an evacuation failure. The expected final state of the evacuation process is a successful (comprehensive) evacuation.

Evacuation due to the way of conducting is divided into:

- orderly, organized,

- chaotic, spontaneous.

The movement of people along escape routes takes various forms. This may be influenced by the emotional stimulation of the participants in this process and the conditions occurring on the escape routes. In case of a small threat, when the participants of the evacuation process are aware of it and do not undergo excessive emotional stimulation, the evacuation process will proceed in an orderly or organized manner. However, when there is niebezpiecznych zdarzeń z udziałem ludzi $w$ trakcie prowadzenia ewakuacji możliwe jest rozłożenie w czasie alarmowania poszczególnych stref pożarowych (alarmowych). Taki zabieg ma na celu niedopuszczenie do powstawania zatorów na drogach ewakuacyjnych, które znacznie spowalniają sam proces ewakuacji, a niekiedy nawet mogą doprowadzić do całkowitego jego zatrzymania. Alarmowanie poszczególnych części budynku wykonane w określonej sekwencji jest prowadzeniem ewakuacji w sposób sekwencyjny. W przypadku braku sekwencji mówimy o ewakuacji równoczesnej. Możliwa jest ona głównie w budynkach jednokondygnacyjnych o prostej architekturze oraz o wielu wyjściach ewakuacyjnych. W przypadku wszystkich budynków wielokondygnacyjnych szczególnie z jedną lub dwoma klatkami schodowymi niezbędne jest rozłożenie w czasie alarmowania poszczególnych stref pożarowych tak, aby na klatkach schodowych nie stworzyć dodatkowego zagrożenia.

Podział ewakuacji ze względu na osobę decydującą o rozpoczęciu ewakuacji:

- samoewakuacja - użytkownik obiektu w wyniku zauważenia zagrożenia podejmuje decyzję o ewakuacji,

- właściciel, zarządca budynku,

- służby ratownicze,

- organy władzy samorządowej

- organy władzy rządowej,

- prezydent państwa.

Decyzja o podjęciu ewakuacji może dokonywać się na różnych poziomach. W przypadku powstania zagrożenia bezpośrednio w otoczeniu człowieka może on podjąć decyzję o likwidacji zagrożenia lub o ewakuacji, jeśli to zagrożenie w jego ocenie jest nie do opanowania. Ewakuacja prowadzona na mocy decyzji pojedynczego użytkownika budynku będzie tzw. samoewakuacją. Ma ona w szczególności miejsce w obiektach, w których nie funkcjonuje system powiadamiania o zaistniałym pożarze, np. budynki mieszkalne wielorodzinne.

Zagrożenie może rozwijać się poza miejscem przebywania użytkowników budynku, a wiedzę w tym zakresie może posiąść jego właściciel lub zarządca. Dbając o bezpieczeństwo użytkowników takiego obiektu to na nich ciąży obowiązek zarządzenia ewakuacji. Może się również tak zdarzyć, że ewakuację zarządzają przybyłe na miejsce służby ratownicze w oparciu o specjalistyczną wiedzę oraz możliwe kierunki rozwoju zagrożenia.

Wszelkiego rodzaju klęski żywiołowe wymagają niejednokrotnie uruchomienia ewakuacji przez osoby reprezentujące organy władzy samorządowej (wójt, burmistrz, prezydent miasta, starosta) lub rządowej (wojewoda, premier). Ostatnim organem mogącym podjąć decyzję o ewakuacji, głównie jako zwierzchnik sił zbrojnych w sytuacji zagrożenia związanego z obronnością kraju, jest prezydent państwa.

Podział ewakuacji ze względu na skuteczność prowadzenia procesu ewakuacji:

- ewakuacja pomyślna, korzystna, udana, kompleksowa, pełna,

- ewakuacja częściowa - niepowodzenie ewakuacji, ewakuacja niepomyślna.

Podział ten ściśle związany jest z celem, dla którego prowadzi się proces ewakuacji. Celem tym jest opuszczenie strefy zagrożenia przez wszystkie znajdujące się w niej osoby. Jeśli z jakiś 
no reliable information about a threat, and the participants of this process rely on guesses or overvalued opinions, excessive emotional arousal may occur, causing an increase in the level of anxiety through fear to horror or even panic. This affects the way people use the escape routes, and the evacuation process can take a chaotic, spontaneous form. An example of a chaotic evacuation as a result of its participants not informing about the degree of danger or even false information about a threat is the evacuation of the Guangzhou Metro Station on April 3, 2014 [55] or on the Republic Square in France on November 15, 2015. A fire protection device designed to carry out evacuation in an organized manner are voice alarm systems. In addition, they allow to provide reliable and verified information about a threat and the expected directions of action of the building users.

Due to the use of direct coercion, evacuation is divided into:

- compulsory

- voluntary.

Ordering an evacuation involves providing this information in the form of a message. In buildings equipped with a fire alarm system, this is very easy and automatic. The problem with notifying building users about the ordered evacuation may occur where there is no broadcast system in the form of a fire alarm system or warning voice alarm system. The ordered evacuation may be understood by users or may be disregarded. People who have a high sense of security at a given moment in the place where they are or low awareness of the effects of the threats may remain in the danger zone. This situation occurs, for example, during the preventive evacuation of areas threatened by a natural disaster in the form of floods. Some residents of floodplains, taking care of their belongings, are able to stay in the danger zone. In such a situation, by virtue of a state of higher necessity, the services responsible for carrying out the evacuation may carry it out using direct coercion.

Division of evacuation due to the object subjected to this process:

- people,

- animals,

- property,

- intangible assets*

* intangible objects requiring protection (e.g. active transactions in the banking system, data of service associates in Afghanistan).

A developing fire poses a threat to the environment. It causes a threat to the life and health of both humans and animals. Property, especially high-value property, is also subject to the evacuation process. An example of such property are all kinds of exhibits in museums and galleries. For each type of evacuated object, there is an appropriate specificity of evacuation.

The issue of the protection of intangible assets is noteworthy. Currently, many activities of people take place in the virtual zone. The collected data and the recorded activities of users in computer systems are sometimes much more valuable than the equipment on which they are collected. In addition, the evacuation of equipment on which data is stored (servers, data carriers) may lead to their damage or loss. In the field of computer science, tools for the so-called migration of data and systems are developing. This migration involves copying critical data and systems przyczyn cel ten nie jest osiągnięty, a osoby pozostają w strefie zagrożenia i są narażone na działanie jego niebezpiecznych czynników, możemy mówić o ewakuacji częściowej lub o niepowodzeniu ewakuacji. Oczekiwanym stanem końcowym prowadzenia procesu ewakuacji jest ewakuacja pomyślna (kompleksowa).

Ewakuację ze względu na sposób prowadzenia dzielimy na:

- uporządkowaną, zorganizowaną,

- chaotyczną, spontaniczną.

Przemieszczanie się ludzi drogami ewakuacyjnymi przybiera różne formy. Wpływ na to może mieć pobudzenie emocjonalne uczestników tego procesu oraz warunki występujące na drogach ewakuacyjnych. W przypadku niewielkiego zagrożenia, gdy uczestnicy procesu ewakuacji są tego świadomi i nie ulegają nadmiernemu pobudzeniu emocjonalnemu proces ewakuacji będzie przebiegał w sposób uporządkowany lub zorganizowany. Natomiast gdy brak jest rzetelnej informacji o zagrożeniu, a uczestnicy tego procesu polegają na domysłach lub przewartościowanych opiniach może dochodzić do nadmiernego pobudzenia emocjonalnego powodującego wzrost poziomu lęku przez strach aż do przerażenia czy nawet paniki. Wpływa to na sposób pokonywania drogi ewakuacyjnej przez ludzi, a proces ewakuacji może przyjąć formę chaotyczną, spontaniczną. Przykładem ewakuacji chaotycznej w wyniku niedoinformowania jej uczestników o stopniu zagrożenia lub wręcz fałszywej informacji o zagrożeniu jest ewakuacja stacji metra w Guangzhou 3 kwietnia 2014 r. [55] lub na placu Republiki we Francji 15 listopada 2015 r. Urządzeniem przeciwpożarowym mającym na celu prowadzenie ewakuacji w sposób zorganizowany są dźwiękowe systemy ostrzegawcze. Pozwalają one dodatkowo na przekazanie rzetelnej i sprawdzonej informacji o zagrożeniu oraz oczekiwanych kierunkach działań użytkowników budynku.

Ze względu na użycie środka przymusu bezpośredniego ewakuację dzielimy na:

- przymusową,

- dobrowolną.

Zarządzenie ewakuacji wiąże się z przekazaniem tej informacji w postaci komunikatu. W budynkach wyposażonych w system sygnalizacji pożarowej jest to bardzo łatwe i przebiega w sposób automatyczny. Problem z powiadomieniem użytkowników budynku o zarządzonej ewakuacji może pojawić się tam, gdzie brak jest systemu rozgłoszeniowego w postaci systemu sygnalizacji pożarowej czy dźwiękowego systemu ostrzegawczego. Zarządzona ewakuacja może spotkać się ze zrozumieniem ze strony użytkowników lub może zostać zlekceważona. Osoby mające wysokie poczucie bezpieczeństwa $w$ danym momencie w miejscu, w którym się znajdują, lub niską świadomość skutków występujących zagrożeń mogą pozostać w strefie zagrożenia. Sytuacja taka ma miejsce chociażby podczas ewakuacji prewencyjnej terenów zagrożonych klęską żywiołową w postaci powodzi. Część mieszkańców terenów zalewowych, dbając o swój dobytek, jest w stanie pozostać w strefie zagrożenia. W takiej sytuacji na mocy stanu wyższej konieczności służby odpowiedzialne za przeprowadzenie ewakuacji mogą zrealizować ją przy użyciu przymusu bezpośredniego.

Podział ewakuacji ze względu na obiekt poddawany procesowi:

- ludzie, 
to devices located in another location (in another building around the world). In the event of a fire, effective and successful data migration over telecommunication links may be a more important process than the protection provided by the evacuation of computer equipment. Server rooms should be designed in such a way that the need to evacuate equipment is brought to a minimum. On one hand, this is achieved by ensuring the functioning of the systems regardless of the fire occurring in the facility (backup electricity supply), appropriate separation of the server room for a time not shorter than the time of the designed fire, on the other hand, care should be taken to equip the server room with the necessary fire protection equipment ( $m$.in extinguishing devices adapted to the type of extinguished device).

According to the conditions the evacuation is carried out:

- in safe conditions,

- under critical conditions.

A fire generates large amounts of energy in the form of heat and radiation, and large amounts of smoke. These factors pose a real threat to human life and health. Therefore, evacuation can be carried out in safe conditions, but also in critical conditions. Evacuation should always be carried out in safe conditions as far as possible. However, if the conditions and available means do not allow it to be carried out in safe conditions, it is carried out in critical conditions. This can cause people to get burns or smoke poisoning, but it will provide survival and rescue. Evacuation in critical conditions occurs mainly as a rescue evacuation. Rescuers, using their specialist knowledge and equipment as a result of an appropriate hazard assessment, can decide to evacuate in critical conditions. An example of such an extreme evacuation is the removal by the rescuers of the unconscious users of the object located in the smoke zone, the direct impact of the fire.

Division of the evacuation according to the stages of its conduct:

- I degree,

- II degree,

- III degree.

First-degree evacuation consists in the immediate movement of people, animals, property from areas and places where there was a sudden, unforeseen immediate threat outside the danger zone. It is implemented immediately at the request of the vogt, mayor or president of the city after the threat to life, health and property occurs. It may also be ordered by the person managing the rescue operation in the area covered by the action. The manager of the rescue operation is obliged to always notify the competent body of local government administration about making such a decision, specifying in particular.

- the area, site, facilities or complex of buildings for which it has ordered evacuation,

- the type of hazard that was the factor determining the announcement of the evacuation,

- the number of evacuees,

- the place to which the evacuation was carried out.

Second-degree evacuation consists in a previously prepared planned movement of people, animals, property from areas adjacent to plants, hydrotechnical facilities, flood zones and areas adjacent to other facilities posing a potential threat
- zwierzęta,

- mienie,

- wartości niematerialne*.

* obiekty niematerialne wymagające ochrony przed zagrożeniem (np. aktywne transakcje w systemie bankowym, dane współpracowników służb w Afganistanie).

Rozwijający się pożar stanowi zagrożenie dla otoczenia. Powoduje on zagrożenie dla życia i zdrowia zarówno ludzi, jak i zwierząt. Mienie, zwłaszcza to o dużej wartości, także podlega procesowi ewakuacji. Przykładem takiego mienia są wszelkiego rodzaju eksponaty w muzeach i galeriach. Dla każdego rodzaju ewakuowanego obiektu funkcjonuje odpowiednia specyfika ewakuacji.

Godna uwagi jest kwestia ochrony wartości niematerialnych i prawnych. Obecnie wiele działań ludzi odbywa się w strefie wirtualnej. Zgromadzone dane oraz zarejestrowane czynności użytkowników w systemach komputerowych są niekiedy o wiele bardziej cenne niż sam sprzęt, na którym są one zgromadzone. Ponadto ewakuacja takiego sprzętu (serwery, nośniki danych) może doprowadzić do ich uszkodzenia lub utraty. W dziedzinie informatyki rozwijają się narzędzia do tzw. migracji danych i systemów. Migracja ta polega na kopiowaniu newralgicznych danych i systemów do urządzeń znajdujących się w innej lokalizacji ( $w$ innym budynku na terenie całego świata). W przypadku pożaru ważniejszym procesem może okazać się skuteczna i zakończona powodzeniem migracja danych przez łącza telekomunikacyjne niż ochrona prowadzona przez ewakuację sprzętu komputerowego. Serwerownie powinny być zaprojektowane tak, aby zminimalizować konieczność ewakuacji sprzętu. $Z$ jednej strony realizuje się to przez zapewnienie funkcjonowania systemów niezależnie od występującego w obiekcie pożaru (rezerwowe zasilanie w energię elektryczną), odpowiednie wydzielenie pomieszczenia serwerowni na czas nie krótszy niż czas projektowanego pożaru, $z$ drugiej strony należy zadbać o wyposażenie pomieszczenia serwerowni w niezbędne urządzenia przeciwpożarowe (m.in. urządzenia gaśnicze dostosowane do rodzaju gaszonego urządzenia).

Podział ze względu na warunki, w jakich prowadzona jest ewakuacja:

- warunki bezpieczne,

- warunki krytyczne.

Pożar generuje duże ilości energii w postaci ciepła i promieniowania oraz duże ilości dymu. Czynniki te stwarzają realne zagrożenie dla życia i zdrowia ludzi. Dlatego ewakuacja może być prowadzona w warunkach bezpiecznych, ale również w warunkach krytycznych. Ewakuację należy zawsze w miarę możliwości prowadzić w warunkach bezpiecznych. Jeśli jednak warunki oraz dostępne środki nie pozwalają na przeprowadzenie jej w warunkach bezpiecznych, prowadzona jest w warunkach krytycznych. Może to powodować u ludzi wystąpienie oparzeń lub zatrucia produktami dymu, jednakże zapewni możliwość przeżycia i uratowania. Ewakuacja w warunkach krytycznych występuje głównie jako ewakuacja ratownicza. Ratownicy korzystając ze swojej specjalistycznej wiedzy i sprzętu w wyniku odpowiedniej oceny zagrożenia, mogą podjąć decyzję o ewakuacji w warunkach krytycznych. Przykładem takiej skrajnej ewakuacji jest wynoszenie przez ratowników nieprzytomnych użytkowników obiektu znajdujących się w strefie zadymienia, bezpośredniego oddziaływania pożaru. 
to the population, animals or property in the event of their damage or failure. It is implemented in the event of symptoms of such a threat.

Evacuation of the third degree consists in a previously prepared movement of people, animals, property during increasing the state of defence readiness of the state. It is conducted during the threat to state security and war. In case of third-degree evacuation, the decision to carry it out is taken by local civil defence bodies or military bodies (in the zone of direct hostilities) in cooperation with a competent civil defence authorities in accordance with the principles set out in the Act of August 29, 2002 on martial law and on the competences of the Supreme Commander of the Armed Forces and the principles of his subordination to the constitutional bodies of the Republic of Poland [56].

Division of evacuations according to the number of the participants:

- single - free, unlimited

- mass - limited.

The course of the evacuation process depends on the size of the group subject to this activity. The flow of people through escape routes is subject to laws similar to the flow of liquid in pipes. In case of a large number of people evacuating at the same time, congestion may occur on the escape routes, and thus slow down the evacuation process. In terms of the number of users, a single evacuation will certainly be a free evacuation and unlimited by the physics of the flow of people along escape routes. On the other hand, mass evacuation will be associated with some kind of restrictions and difficulties in overcoming the escape route. Mass evacuation largely causes the risk of injuries among its participants.
Podział ewakuacji ze względu na etapy jej prowadzenia:

- I stopnia,

- II stopnia,

- III stopnia.

Ewakuacja I stopnia polega na niezwłocznym przemieszczeniu ludności, zwierząt, mienia z obszarów i miejsc, w których wystąpiło nagłe, nieprzewidziane bezpośrednie zagrożenie poza strefę zagrożenia. Realizuje się ją natychmiast po zaistnieniu zagrożenia dla życia, zdrowia i mienia na polecenie wójta, burmistrza lub prezydenta miasta. Może ją także zarządzić osoba kierująca akcją ratunkową na terenie objętym daną akcją. Kierujący akcją ratowniczą zobowiązany jest każdorazowo powiadomić właściwy organ administracji samorządowej o podjęciu takiej decyzji, podając w szczególności:

- rejon, teren, obiekty lub zespół budynków, dla którego zarządził ewakuację,

- rodzaj zagrożenia, który był czynnikiem determinującym ogłoszenie ewakuacji,

- liczbę ewakuowanych,

- miejsce, do którego dokonano ewakuacji.

Ewakuacja II stopnia polega na uprzednio przygotowanym planowym przemieszczeniu ludności, zwierząt, mienia z rejonów przyległych do zakładów, obiektów hydrotechnicznych, ze stref zalewowych oraz rejonów przyległych do innych obiektów stanowiących potencjalne zagrożenie dla ludności, zwierząt lub mienia w przypadku ich uszkodzenia lub awarii. Realizuje się ją w sytuacji wystąpienia symptomów takiego zagrożenia.

Ewakuacja III stopnia polega na uprzednio przygotowanym przemieszczeniu ludności, zwierząt, mienia podczas podwyższania stanu gotowości obronnej państwa. Prowadzona jest w czasie zagrożenia bezpieczeństwa państwa oraz wojny. W przypadku ewakuacji III stopnia decyzję o jej przeprowadzeniu podejmują terenowe organy obrony cywilnej lub organy wojskowe (w strefie bezpośrednich działań wojennych) we współdziałaniu z właściwymi organami obrony cywilnej zgodnie z zasadami określonymi w ustawie $z$ dnia 29 sierpnia 2002 r. o stanie wojennym oraz o kompetencjach Naczelnego Dowódcy Sił Zbrojnych i zasadach jego podległości konstytucyjnym organom Rzeczypospolitej Polskiej [56].

Podział ewakuacji ze względu na liczebność uczestników:

- pojedyncza - swobodna, nieograniczona,

- masowa - ograniczona.

Przebieg procesu ewakuacji uzależniony jest od liczebności grupy podlegającej tej czynności. Przepływ ludzi drogami ewakuacyjnymi podlega prawom podobnym do przepływu cieczy w rurach. W przypadku dużej liczby osób ewakuujących się równocześnie może dochodzić do powstawania zatorów na drogach ewakuacyjnych, a tym samym spowolnienia procesu ewakuacji. Pod względem liczebności użytkowników ewakuacja pojedyncza z pewnością będzie ewakuacją swobodną i nieograniczoną przez fizykę przepływu ludzi drogami ewakuacyjnymi. Natomiast ewakuacja masowa będzie wiązała się z pewnego rodzaju ograniczeniami oraz trudnościami w pokonaniu drogi ewakuacyjnej. Ewakuacja masowa w znacznym stopniu powoduje zagrożenie powstania urazów i obrażeń wśród jej uczestników. 


\section{Summary}

The authors submit to public discussion the proposed criteria for the division of the evacuation process and its definition. The analysis shows that evacuation is a very complex process. This process takes many forms, and each of these forms is characterized by different specifics. Depending on the form of evacuation, there are different approaches to its planning, organization and management.

Another element that speaks in favour of the need to clarify the definition of the evacuation process and determine its types is the possibility of conducting safety analysis for its individual types. Without additional detailed analysis, we can say that full-simultaneous evacuation, in which the number of participants will cause restrictions on escape routes, is much more dangerous than full-sequential evacuation with a small number of people evacuating. Systematization of the issue will bring measurable benefits to the field of fire engineering allowing to express the same types of evacuation with one type of adjectives and terms.

\section{Conclusion}

The analysis shows that the concept of evacuation has a broader meaning than it appears from the definitions introduced so far. Evacuation should be defined as the process of moving people, animals or property from a place of danger to a place that is currently safe. For the purposes of this article, a total of more than 25 evacuation process determinations have been identified, which have been classified into 12 categories. Progress in many areas, i.e. construction, development of transport, urban infrastructure and the occurrence of public demonstrations, events affects the need to verify existing definitions for the needs of new conditions. The publication aims to draw attention to the need to introduce a systematic classification of the evacuation process. Such classification will allow for the proper identification of all kinds of variables affecting the various forms of this process. The introduction of the classification will allow the use of appropriate measures, tools and procedures to ensure an adequate level of human safety. The classification carried out may be the basis for identifying the hazards that may occur during individual forms of evacuation.

\section{Literature / Literatura}

[1] Konstytucja Rzeczypospolitej Polskiej z dnia 2 kwietnia 1997 r. (Dz. U. 1997 nr 78, poz. 483 ze zm.).

[2] Ustawa z dnia 7 lipca 1994 r. - Prawo budowlane (tj. Dz. U. 2020, poz. 1333 ze zm.).

[3] Rozporządzenie Ministra Infrastruktury z dnia 12 kwietnia 2002 r. w sprawie warunków technicznych jakim powinny odpowiadać budynki i ich usytuowanie (tj. Dz. U. 2019, poz. 1065 ze zm.).

\section{Podsumowanie}

Autorzy poddają do publicznej dyskusji proponowane kryteria podziału procesu ewakuacji oraz jego definiowania. Z przeprowadzonej analizy wynika, że ewakuacja jest procesem bardzo złożonym. Proces ten przyjmuje wiele form, a każda z tych form charakteryzuje się odmienną specyfiką. W zależności formy prowadzenia ewakuacji występują odmienne podejścia do jej planowania, organizacji oraz kierowania.

Kolejnym elementem przemawiającym za koniecznością uściślenia definicji procesu ewakuacji oraz określenia jej rodzajów jest możliwość prowadzenia analizy bezpieczeństwa dla poszczególnych jej rodzajów. Bez dodatkowej szczegółowej analizy możemy powiedzieć, że ewakuacja pełna-równoczesna, w której liczba uczestników spowoduje ograniczenia na drogach ewakuacyjnych jest znacznie bardziej niebezpieczna od ewakuacji pełnej-sekwencyjnej z małą liczbą ewakuujących się osób. Usystematyzowanie zagadnienia przyniesie dziedzinie inżynierii pożarowej wymierne korzyści pozwalające na wyrażanie tych samych rodzajów ewakuacji jednym rodzajem przymiotników i określeń

\section{Wnioski końcowe}

Z analizy wynika, że pojęcie ewakuacji ma szersze znaczenie niż wynika to $z$ dotychczas wprowadzonych definicji. Ewakuację należy definiować jako proces przemieszczania ludzi, zwierząt lub mienia z miejsca zagrożenia do miejsca aktualnie bezpiecznego. Na potrzeby niniejszego artykułu zidentyfikowano łącznie ponad 25 określeń procesu ewakuacji, które zostały sklasyfikowane według 12 kategorii. Postęp w wielu dziedzinach tj. budownictwo, rozwój transportu, infrastruktury miast oraz występowania publicznych manifestacji, imprez wpływa na potrzebę weryfikowania istniejących definicji na potrzeby nowych uwarunkowań. Publikacja ma na celu zwrócenie uwagi na konieczność wprowadzenia usystematyzowanej klasyfikacji procesu ewakuacji. Klasyfikacja taka pozwoli na właściwą identyfikację wszelkiego rodzaju zmiennych mających wpływ na różne formy tego procesu. Wprowadzenie klasyfikacji pozwoli na zastosowanie odpowiednich środków, narzędzi oraz procedur do zapewnienia odpowiedniego poziomu bezpieczeństwa ludzi. Przeprowadzona klasyfikacja może być podstawą do zidentyfikowania zagrożeń mogących występować podczas prowadzenia poszczególnych form ewakuacji.
[4] Rozporządzenie Parlamentu Europejskiego i Rady (WE) nr 1137/2008 z dnia 22 października 2008 r. dostosowujące do decyzji Rady 1999/468/WE niektóre akty podlegające procedurze ustanowionej w art. 251 Traktatu, w zakresie procedury regulacyjnej połączonej z kontrolą - Dostosowanie do procedury regulacyjnej połączonej z kontrolą (Dz. U. UE. L. 2008.311.1).

[5] BSI (British Standards Institution), Application of fire safety engineering principles to the design of buildings - Human 
factors. Life safety strategies. Occupant evacuation, behaviour and condition (Sub-system 6), BS 7974-6, Londyn 2019.

[6] BSI (British Standards Institution), Code of practice for the design, installation, commissioning and maintenance of evacuation alert systems for use by fire and rescue services in buildings containing flats, BS 8629, Londyn 2019.

[7] BSI (British Standards Institution), Fire detection and fire alarm systems. Planning, design, installation, commissioning, use and maintenance of voice alarm systems, PD CEN/TS 54-32:2015, Londyn 2015.

[8] Hurley M. J., i in., SFPE handbook of fire protection engineering, Springer, 2015, https://doi.org/10.1007/978-1-4939-2565-0.

[9] Lewis Ch. T., Short Ch., A Latin Dictionary, Nowy Jork 1879.

[10] Kolmann P., Z problematyki ochrony ludności. Istota ewakuacji w ujęciu powszechnym , "O Bezpieczeństwie i Obronności" 2020, nr 1, s. 88-98.

[11] Leśniakiewicz W., Wytyczne szefa obrony cywilnej kraju z dnia 17 października 2008 r. w sprawie zasad ewakuacji ludności, zwierząt i mienia na wypadek masowego zagrożenia, Warszawa 2008.

[12] PKN (Polski Komitet Normalizacyjny), Ochrona przeciwpożarowa - Terminologia - Ewakuacja i środki ewakuacji, PN-ISO 8421-6:1997, Warszawa 1997.

[13] NFPA (National Fire Protection Association), Standard on Mass Evacuation, Sheltering, and Re-entry Programs, NFPA 1616, Massachusetts 2020.

[14] Yujie W., Bhattacharya Y., Nakamura H., Safety Evaluation of an Urban Redevelopment Area as an Evacuation Area for Large-Scale Urban Fires, „SEATUC Journal of Science and Engineering" 2021, 2(1), 40, https://doi.org/10.34436/sjse.2.1_40.

[15] Nepelski M., Zarządzanie w sytuacjach kryzysowych, Wyższa Szkoła Policji w Szczytnie, Szczytno 2016.

[16] Fałdowski M., Współczesny wymiar bezpieczeństwa, "Zeszyty Naukowe SGSP" 2018, 66(2), 109-122.

[17] Olak K., Olak A., Współczesne rozumienie bezpieczeństwa narodowego, „Acta Scientifica Academiae Ostroviensis. Sectio A, Nauki Humanistyczne, Społeczne i Techniczne" 2016, 7(1), 467-480.

[18] Ustawa z dnia 6 czerwca 1997 r. Kodeks karny (tj. Dz. U. 2020 poz. 1444 ze zm.).

[19] Szczypta R., Wymagania przeciwpożarowe w zakresie aranżacji przestrzeni $w$ budynkach według obowiązujących przepisów i stanowiska KG PSP, Warszawa 2014, http://sibp.pl/uploads/pages/materialy/szczypta.pdf [dostęp: 10.11.2021].

[20] Kobes M., Helsloot I., De Vries B., Post J.G., Building safety and human behaviour in fire: A literature review, "Fire Safety Journal" 2010, 45, https://doi.org/10.1016/j. firesaf.2009.08.005.

[21] Maciak T., Barański M., Wprowadzenie do komputerowego modelowania zachowania się tłumu. Wybrane aspekty psychologii tłumu, BiTP Vol. 40 Issue 4, 2015, pp. 39-49, https://doi.org/10.12845/bitp.40.4.2015.3.

[22] Decree of the minister of the interior 2 August 2015 Approval of fire prevention technical standards, pursuant to Article 15 of Legislative Decree 139 of 8 Mar. 2006.
[23] Babrauskas V., Fleming J.M., Russell B.D., RSET/ASET, a flawed concept for fire safety assessment, "Fire and Materials" 2010, 34, 341-355, https://doi.org/10.1002/fam. 1025.

[24] Purser D.A., Fire safety and evacuation implications from behaviours and hazard development in two fatal care home incidents, „Fire and Materials” 2015, 39(4), 430-452, https://doi.org/10.1002/fam.2250.

[25] Popielarczyk T., Ewakuacja ludzi z wykorzystaniem dźwiękowych systemów ostrzegawczych, Wyd. CNBOP-PIB, Józefów 2018.

[26] Słownik języka polskiego, PWN, https://sjp.pwn.pl/ [dostęp: 10.11.2021].

[27] Smolarkiewicz M., Techniki Satelitarne w Zarządzaniu Kryzysowym - Studium Użyteczności, BiTP Vol. 14 Issue 2, 2009, pp. 39-50.

[28] Pauls J., Calculating evacuation times for tall buildings, „Fire Safety Journal” 1987, 12(3), 213- 236, https://doi. org/10.1016/0379-7112(87)90007-5.

[29] Sulik P., Sędłak B, Turkowski P., Węgrzyński W., Bezpieczeństwo pożarowe budynków wysokich i wysokościowych, w: Budownictwo na obszarach zurbanizowanych, Nauka, praktyka, perspektywy, A. Halicka (red.) Politechnika Lubelska, Lublin 2014.

[30] Gromek P., Jarzynka K., Grabowska I., Ewakuacja I stopnia placówki oświatowej - podejście projektowe. Wprowadzenie, "Zeszyty Naukowe SGSP” 2017, 63(3), 7-19.

[31] Gravit M., Dmitriev I., Kuzenkov K., Phased evacuation algorithm for high-rise buildings, "MATEC Web of Conferences” 2018, 245, https://doi.org/10.1051/matecconf/201824511012.

[32] Parisi D. R., Negri P. A., Sequential evacuation strategy for multiple rooms toward the same means of egress, "Papers in Physics" 2014, 6, https://doi.org/10.4279/PIP.060013.

[33] Źróbek R., Ogoniewski M., Piotrowski M., Zasady usprawnienia wybranych procedur ewakuacji w procesie zarządzania nieruchomościami, „Acta Scientiarum Polonorum. Administratio Locorum" 2014, 13(1), 45-55.

[34] Juras B., Planowanie zarządzania kryzysowego w szpitalu, rozprawa doktorska, Uniwersytet Medyczny w Poznaniu, Poznań 2011.

[35] Li J., Zhu H., A risk-based model of evacuation route optimization under fire, „Procedia Engineering” 2018, 211, https://doi.org/10.1016/j.proeng.2017.12.024, 365-371.

[36] Brzezińska D., Ollesz R., Wentylacja oddymiająca w garażach - rozwiązania kontrowersyjnych problemów na przykładach projektowych, BiTP Vol. 45 Issue 1, 2017, pp. 130-141, doi: 10.12845/bitp.45.1.2017.10.

[37] Hulida E., Pasnak I., Koval O., Tryhuba A., Determination of the critical time of fire in the building and ensure successful evacuation of people, „Periodica Polytechnica Civil Engineering" 2019, 63(1), 308-316, https://doi.org/10.3311/ PPci. 12760.

[38] Gromek P., Organizacja masowej ewakuacji ludności w Polsce, rozprawa doktorska, AON, Warszawa 2014.

[39] Szwemin S., Praktyczne aspekty identyfikacji zagrożeń podczas planowania ewakuacji ludności na wypadek konfliktu zbrojnego, „Przedsiębiorstwo i Praca” 2021, 11. 
[40] Hong L., Gao J., Zhu W., Self-evacuation modelling and simulation of passengers in metro stations, "Safety Science" 2018, 110, 127-133, https://doi.org/10.1016/j. ssci.2018.05.013.

[41] Gromek P., Aspekt społeczny analizy ryzyka ewakuacji ludności w obliczu klęski żywiołowej w Polsce, „Prace i Studia Geograficzne" 2014, 55, 43-53.

[42] Doroszewski W., Słownik języka polskiego, Wiedza Powszechna, Warszawa 1969.

[43] Barć M., Zarządzanie ewakuacją ludności i mienia podczas zagrożeń niemilitarnych przez oddziały i pododdziały Sił Zbrojnych RP, "Roczniki Ekonomii i Zarządzania” 2017, 9(2), 61-78.

[44] Riegert D., Ślosorz Z., Radwan K., Rakowska J., Porycka B., Abgarowicz I., Suchorab P., Doraźne metody ochrony stosowane podczas powodzi ze szczególnym uwzględnieniem rękawów przeciwpowodziowych, Wydawnictwo CNBOP-PIB, Józefów 2012.

[45] Wielkopolski Urząd Wojewódzki w Poznaniu, Ewakuacja ludności, https://www.poznan.uw.gov.pl/ewakuacja-ludnosci [dostęp: 08.09.2021].

[46] Węgrzyński W., Krajewski G., Wentylacja pożarowa tuneli drogowych, "Materiały Budowlane" 2015, 2, 14-16, https://doi.org/10.15199/33.2015.02.03.

[47] Sochacki M., Trzydzieści lat ratownictwa wysokościowego w ochronie przeciwpożarowej, „Kwartalnik Bezpieczeństwo i Technika Pożarnicza" 2009, 16, 21-34.

[48] Marciniak A., Boczarski J., Budziński Z., Jarosławska-Kolman K., Analiza porównawcza głównych wymagań przepisów polskich i brytyjskich w zakresie przygotowania terenów wokół budynków doprowadzenia ewakuacji interwencyjnej, „Logistyka” 2015, 5, 1129-1134.

[49] Szylar J., Szkolenie Strażaków Ratowników OSP z zakresu działań przeciwpowodziowych oraz ratownictwa na wodach, Wydawnictwo CNBOP-PIB, Józefów 2009.

[50] Gromek P., Efektywne ewakuacje próbne, „Doradca Dyrektora Szkoły" 2012, 19, s. 22-24.

[51] Cłapa I., Instrukcja bezpieczeństwa pożarowego, scenariusz pożarowy oraz próbna ewakuacja jako kluczowe elementy zarządzania systemem bezpieczeństwa pożarowego budynku, BiTP Vol. 40 Issue 4, 2015, 123-131.

[52] Chudy S., Ćwiczenia ewakuacyjne w zakładach pracy, "Promotor BHP" 2016, 4, 42-45.

[53] Santos A., Queirós M., Public buildings safety: addressing a pilot evacuation exercise, w: T. Nowakowski, Safety and Reliability: Methodology and Applications, CRC Press 2015.

[54] Rozporządzenie Ministra Spraw Wewnętrznych i Administracji z dnia 7 czerwca 2010 r. w sprawie ochrony przeciwpożarowej budynków, innych obiektów budowlanych i terenów (Dz. U. 2010 nr 109, poz. 719 ze zm.).

[55] Zhao H., Sun Y., Communication effect of passengers on information diffusion in metro emergency, "Wuhan University Journal of Natural Sciences" 2017, 22(6), 503-509, https://doi.org/10.1007/s11859-017-1280-z.

[56] Ustawa z dnia 29 sierpnia 2002 r. o stanie wojennym oraz o kompetencjach Naczelnego Dowódcy Sił Zbrojnych i zasadach jego podległości konstytucyjnym organom Rzeczypospolitej Polskiej (Dz. U. 2017, poz. 1932).
SENIOR CPT. MARIUSZ BARAŃSKI, M.SC. ENG. - currently, a PhD student at the Lodz University of Technology, Faculty of Process Engineering and Environmental Protection, cooperating with Dorota Brzezińska, PhD Eng. A graduate of the School of Aspirants of the State Fire Service in Kraków, the Main School of Fire Service and the Wrocław University of Technology. Member of the Board of the Lower Silesian Branch of the Association of Fire Engineers and Technician. An officer of the State Fire Service with 17 years of professional experience. Currently a senior specialist in the Inspection and Reconnaissance Department of the Provincial Headquarters of the State Fire Service in Wrocław. The subject of his interests are issues related to the evacuation process and its modelling, in particular the evacuation of buildings. Author of articles in, inter alia, CNBOP-PIB quarterly Safety \& Fire Technology, Scientific Journals of the Main School of the Fire Service.

AGNIESZKA HAZNAR-BARAŃSKA, M.SC. - a graduate of the University of Economics in Wrocław. A long-time member of the Volunteer Fire Department in Oława, and a long-time employee of public institutions (the District Prosecutor's Office, the County Headquarters of the State Fire Service, the Roads and City Greenery Authority). He has extensive knowledge in the field of public safety, including fire safety.
ST. KPT. MGR INŻ. MARIUSZ BARAŃSKI - obecnie doktorant Politechniki Łódzkiej na Wydziale Inżynierii Procesowej i Ochrony Środowiska współpracujący z dr hab. inż. Dorotą Brzezińską. Absolwent Szkoły Aspirantów Państwowej Straży Pożarnej w Krakowie, Szkoły Głównej Służby Pożarniczej oraz Politechniki Wrocławskiej. Członek Zarządu Oddziału Dolnośląskiego Stowarzyszenia Inżynierów i Techników Pożarnictwa. Funkcjonariusz Państwowej Straży Pożarnej z 17-letnim doświadczeniem zawodowym. Obecnie starszy specjalista w Wydziale Kontrolno-Rozpoznawczym Komendy Wojewódzkiej Państwowej Straży Pożarnej we Wrocławiu. Przedmiotem jego zainteresowań są zagadnienia związane z procesem ewakuacji oraz jego modelowania, w szczególności ewakuacji budynków. Autor artykułów na łamach m.in. Kwartalnika BiTP, Safety \& Fire Technology, Zeszytów Naukowych SGSP.

MGR AGNIESZKA HAZNAR-BARAŃSKA - absolwentka Uniwersytetu Ekonomicznego we Wrocławiu. Wieloletni członek Ochotniczej Straży Pożarnej w Oławie oraz wieloletni pracownik instytucji publicznych (Prokuratura Rejonowa, Komenda Powiatowa Państwowej Straży Pożarnej, Zarząd Dróg i Zieleni Miejskiej). Posiada szeroką wiedzę z zakresu bezpieczeństwa publicznego, w tym bezpieczeństwa pożarowego. 